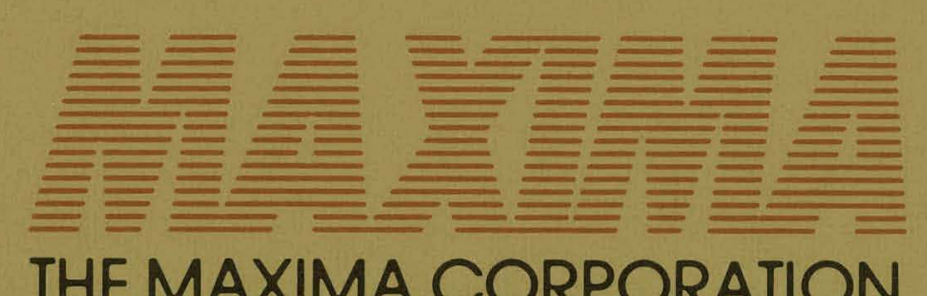

\author{
REPORT ON AN \\ ANALYSIS OF \\ SELECTED \\ EIA PUBLICATIONS
}

Prepared by

The MAXIMA Corporation

October 1980

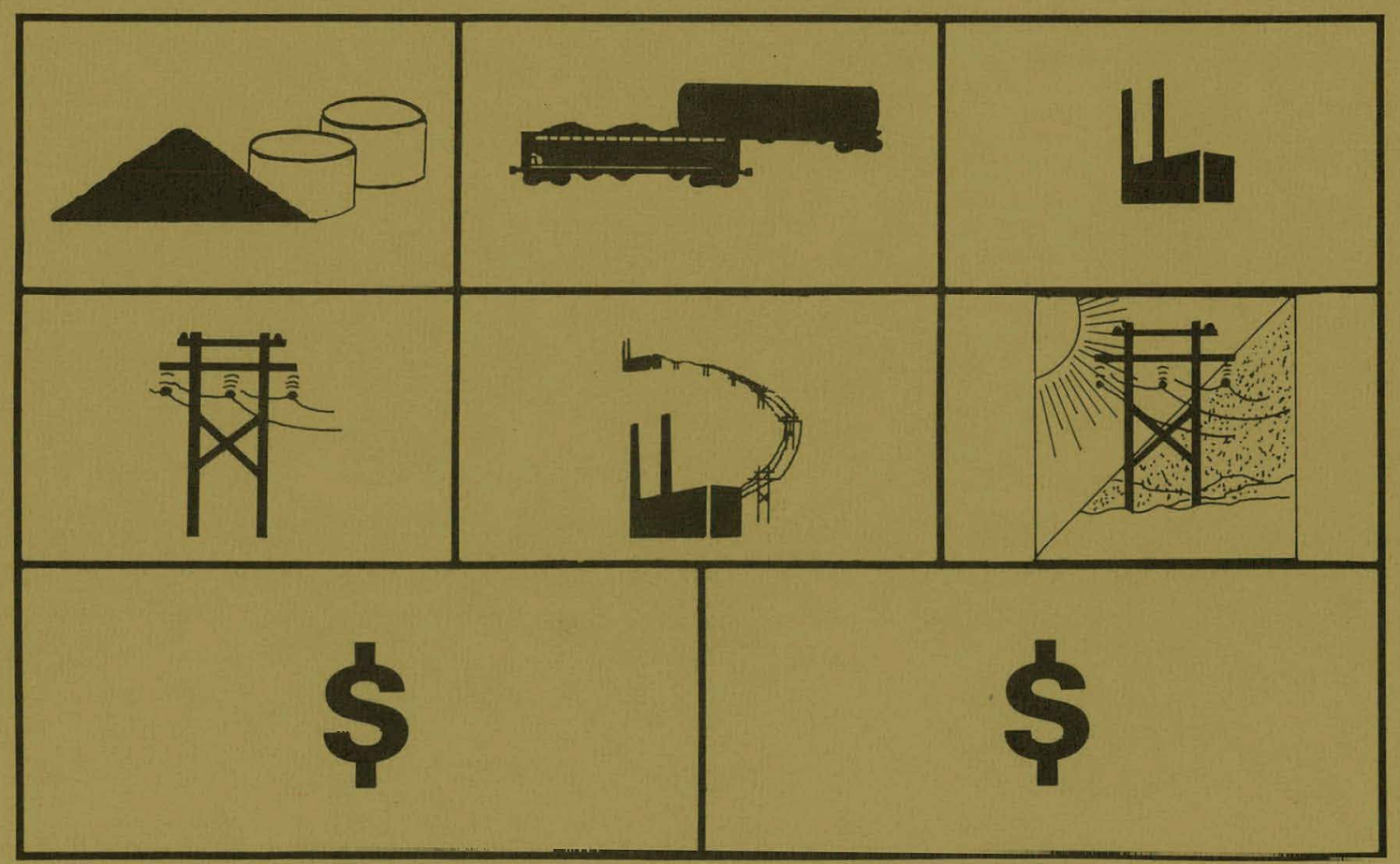

DASTRNUTHEA of THIS ROCUMENT IS UALIMITEO 


\section{DISCLAIMER}

This report was prepared as an account of work sponsored by an agency of the United States Government. Neither the United States Government nor any agency Thereof, nor any of their employees, makes any warranty, express or implied, or assumes any legal liability or responsibility for the accuracy, completeness, or usefulness of any information, apparatus, product, or process disclosed, or represents that its use would not infringe privately owned rights. Reference herein to any specific commercial product, process, or service by trade name, trademark, manufacturer, or otherwise does not necessarily constitute or imply its endorsement, recommendation, or favoring by the United States Government or any agency thereof. The views and opinions of authors expressed herein do not necessarily state or reflect those of the United States Government or any agency thereof. 


\section{DISCLAIMER}

Portions of this document may be illegible in electronic image products. Images are produced from the best available original document. 


\title{
REPORT ON AN ANALYSIS OF SELECTED \\ EIA PUBLICATIONS
}

\author{
Prepared by \\ The MAXIMA Corporation \\ October 1980
}

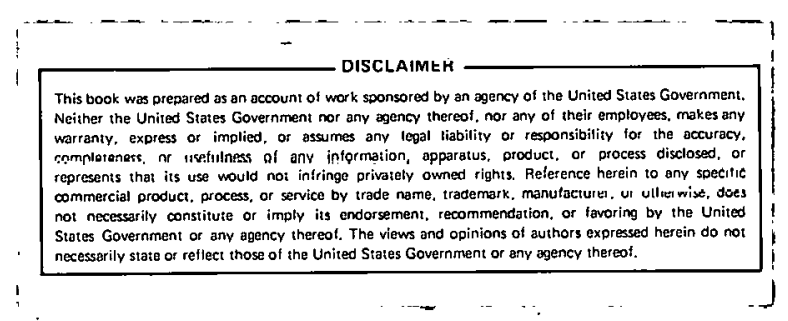

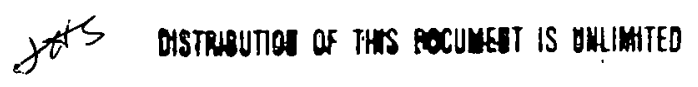




\section{Executive Summary}

This report represents the results of our critical analysis of the current version of the publication entitled Electric Power Monthly (EPM). The report includes specific recommendations for improving the publication. Organization, information comparability and table and graph format have been reviewed and criticized by our publications staff and recommendations for improving each of these have been made.

The report consists of three sections including a general review of the publication, a review of the data tables included in the publication and a review of graphics included in the publication. The report addresses substantive as well as cosmetic issues pertaining to the publication in each of the three sections.

Highlights of our recommendations are as follows:

- Develop an executive summary emphasizing national data.

- Expand narrative description to include the purpose of the publication.

- Separate volumetric and economic content of the report.

- Organize data presented in volumetric and economic sections to reflect the process of electric generation.

- Reorganize data presentation to conform to the convention of presenting aggregate data first followed by disaggregated data. Furthermore, U.S. Totals should be placed in the front of each chapter where possible.

- Improve the accuracy of graphic representations in the publication. 
- Standardize whenever possible the following items on graphs and tables:

- Number of states included

- Number of months covered

- Measures and terms used.

- Improve table titles and footnotes.

- Expand "Source Note" to include percent of universe covered.

- Add explanatory notes at the end of each chapter.

- Reduce the number of pages devoted to NERC graphics by plotting more than one region (up to three) on one graph.

- Reduce the size of the graphic representations by 25 percent.

These recommendations are the results of our analysis of the publication content, purpose and format. In the remaining sections of the report, we we will expand on the rationale behind each recommendation and give examples of improvements that can be made to the various parts of the publication. 


\section{Introduction}

The purpose of this report is to detail our analysis of the current version of the Electric Power Monthly (EPM) publication. We have reviewed the publication and its component parts and have made recommendations, where necessary, to improve its readability and data comparability. During this process, we have also reviewed the Energy Information Administration's (EIA) publication standards and the capabilities of the EIA computer graphics package. Except where noted, the recommendations within this report conform to EIA standards and are within the limitations of the current graphics system. We have recommended solutions deviating from these standards and limitations only when significant improvement in the publication will result. Where appropriate, EIA standards should be reexamined for possible modification.

The review and recommendations detailed within this report have been divided into three major areas:

- Review of Overall Publication

- Review of Tables

- Review of Graphs

Each of these has been further divided into two areas. 'The first, Substantive Review, concentrates on the organization and comparability of the data. The second area, Cosmetic Review, focuses on the graphic presentation of the data. 


\section{Overall Review of Publication}

This section addresses issues that pertain to the entire publication. The section is divided into two major parts. The first part entitled Substantive Review, consists of a review of the organization and comparability of the information within the EPM and subsequent recommendations for improvement where necessary. The second part of this section entitled Cosmetic Review, is devoted to making recommendations for improving the format for presenting information in the publication.

\section{Substantive Review}

The following topics are discussed in the Substantive Review of the publication:

- Overall Organization

- Graph and Table Ordering

- Graph and Table Comparability

In each of these sections we have described and reviewed the current state of the publication, made recommendations for improvement where appropriate, and have given the rationale behind each recommended change. Except where noted, all recommendations conform to EIA standards and current EIA graphics capabilities. Recommendations not conforming th these standards and 1imitations, have been made only when significant improvement will result.

\section{Overall Organization}

1. Introductory Materials

The most important section of the publication is the beginning where the reader is introduced to the information in the Electric Power Monthly (EPM). 
Currently, the introductory materials in the EPM are too sparse. We recommend that an executive summary be added and the Scope of Publication be expanded to include the purposes of the EPM.

The executive summary should preview the order and contents of the publication using national figures and should highlight significant increases or decreases in the national totals. Additionally, the actual amount of change should be expressed in percentages rather than absolute amounts. Examples of this approach are as follows:

Receipts of Fuels for the Generation of Electricity

During December 1979, U.S. utility coal receipts, excluding petroleum coke, decreased 5.9 percenl (adjusled) vier those of Novcmber ( 47.6 versus 49.0 million short tons). These figures include bituminous coal (with a decrease of 9.3 percent) and sub-bituminous coal (with an increase of 6.1 percent). December 1979 U.S, utility oil deliveries increased 13.2 percent over the previous month (43.9 versus 37.5 million barrels) with heavy oil increasing 12 percent and light oil increasing 29.8 percent. Gas deliveries for December 1979 decreased 7.8 percent ( 240.8 versus 252.5 billion culic feet) with natural gao decreasing 7.8 percent and other gases increasing 5.9 percent.

Costs of Fuels for the Generation of Electric1ey

In December 1979, average coal prices increased .87 percent over the previous month ( $\$ 27.46$ versus $\$ 27.22$ per short ton) with contract coal purchases increasing .38 cents to $\$ 27.10$ per ton and spot coal costs decreasing . 50 cents to an average of $\$ 29.81$ per ton. 0il costs increased 3.7 percent over the previous month $(\$ 24.73$ versus $\$ 22.76$ per barrel). The average cost of No. 6 fuel oil increased $\$ 1 . y 3$ per barrel to $\$ 24.47$, and No. 2 fuel ofl Increased $\$ 2.24$ per barrel to $\$ 32.91$. Average gas costs increased .03 cents per thousand cubic feet to $\$ 1.89$ per million cubic feet as compared to November. Firm and interruptible gas receipts averaged $\$ 1.60$ per million cubic feet and $\$ 2.46$ per million cubic feet, respectively, over November 1979. 
Also, the current introduction to the publication does not describe the purpose of the EPM. We recommend that a paragraph, describing the purpose and use of the EPM, should also be included in the Scope of Publication as an aid to readers. Exhibit 1. represents our suggested format for the Scope of Publication.

\section{Publication Content}

The functional or subjective rationale for the placement of chapters and sections in the current version of the EPM is unclear. The current version is organized in the following way:

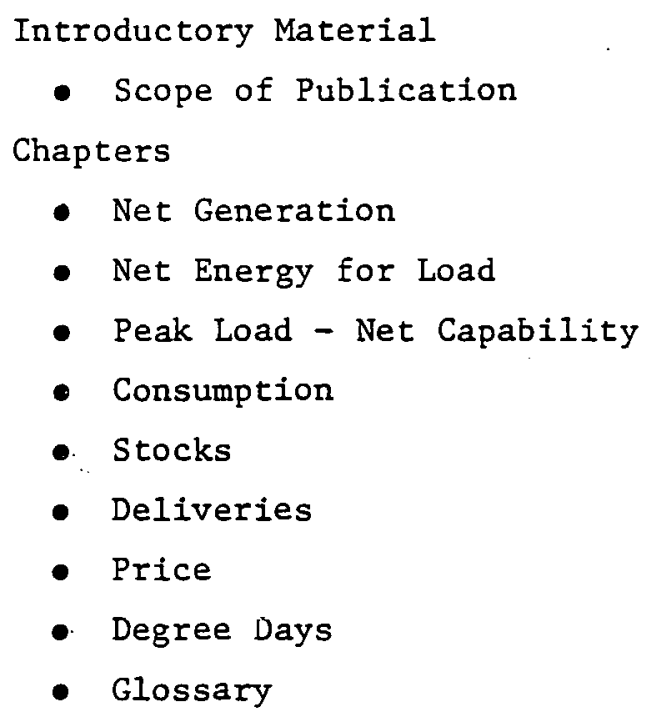

Ending Materials

- Conversion Table

- Appendix

- Reader's Comment Form

- Related Publication

We recommend that the chapters of the EPM be separated into two major sections - Volumetric Information, and Cost and Pricing Information. Although the data which would be presented in these two parts have a relationship tu une another, they should be separated for a number of reasons.

- Statistical convention requires that data be presented in groups which are generically similar, allowing them to be compared and verified. 


\section{A. Description and Scope of Publication}

\section{Electric Power Monthly}

The Electric Power Monthly is prepared by the Division of Electric Power Statistics, office of Coal and Electric Power Statistics, Energy Information Administration, Department of Energy.

The intent of this publication is to provide accessible information about electric utility power generation in a format that is clear, concise and appropriate. Because the variety of uses to which the data can be applied are numerous, and because of the important role which energy decision-making plays in contemporary society, the Electric Power Monthly has been designed for use by electric utilities, consumers, commercial businesses, universities and government.

The Electric Power Monthly presents monthly summaries of electric utility statistics at the national, regional, state or local levels on the following subjects:

- Stocks of Fuel for the Generation of Electricity

- Receipts of Fuel for the Generation of Electricity

- Consumption of Fùel for Generation of Electricity

- Net Electrical Generation

- Net Electrical Energy for Load

- Peak Load Electricity Demand and Net Capability

- Cost of Fuels for the Generation of Electricity

- Retall Electricity Prices

Each of these subjects is treated as a separate chapter in this publication with volumetric and cost and pricing data further separated for easier comparability.

\section{Sources of Data}

The electric utility data published in the Electrio Powcr Monthly are compiled from four statistical forms filed monthly by the Energy Information Administration. The form numbers and titles are given in Figure 1 and on each chart and table in the publication.

\section{Coverage of Sources}

The Form 4 data source represents 100 percent coverage of electric utjlities with generating plants. However, none of the remaining three data sources represents 100 percent coverage of its field, as shown in Figure 1. The coverage of each form is given on each chart and table in the publication.

The National Electric Reliability Council (NERC) data presented in this publication are limited to that portion applicable to the contiguous United States, thereby excluding that portion of NERC data applicable to the provinces in Canada. Also, in all tables excepting those in the Receipts Section and the Price Section, data from Alaska and Hawaii, which are not associated with a NERC council area, are added to the 48 state subtotal to give a 50 state total. A map showing the NERC council areas is shown in Figure 2.

\section{Adjustments to Basic Data}

No adjustments have been made to basic data. If it is necessary to extend source data to obtain 100 percent coverage, refer to the 'Coverage of Sources' entries in Figure 1.

\section{Explanatory Notes}

Explanatory notes have been provided to give practical definitions of electric utility terms and source information. The notes are at the end of each chapter and define each term within that chapter.

\section{Appendices}

Information about heating degree days, a thermal conversion chart and an overall glossary have been provided in Appendices A, $\mathrm{B}$, and $\mathrm{C}$.

\section{Reader's Comment Form}

Your views concerning this publication will increase its usefulness. All comments regarding the accuracy, completeness, and organization will be appreciated. For your convenience, we have attached a solf-addressed Reader's Comment Form at the back of this report.

\section{Description of a Related Publication}

To inform the reader of other electric power-related reports published by the Division of Electric Power Statistics, the inside of the back cover will carry the description of a different report each month.

Exhibit 1. Description and Purpose of Publication 
- Certain economic and physical processes, i.e., input/output flows, balance equations, can be followed and interpreted more easily than when price and volume data are separated. For example, coal stocks data are presented simply as a report of the amount of coal used by various regions and states to produce electricity. The comparable price information, on the other hand, is reported by "type of mining method", which in turn is broken down into quantity, cents $10^{6}$ Btu and dollars per ton.

The chapter organization within these two sections should, where possible, reflect the process by which electricity is generated. To correspond to this process, we recommend that the chapters be reordered as follows:

VOLUMETRIC INFORMATION

1. Stocks

2. Receipts (originally "Deliveries")

3. Consumption

4. Net Generation

5. Net Energy for Load

6. Peak Load Electricity Demand - Net Capability

COST AND PRICING INFORMATION

1. Cost of Fuel (originally "Prices")

2. Retail Prices (originally "Prices")

We recommend that titles be changed to identify, more specifically, the data presented in each chapter. We suggest the use of the following titles for chapters in the iepurl:

- Stocks of Fuel for the Generation of Electricity

- Receipts of Fuel for the Generation of Electricity

- Consumption of Fuel for the Generation of Electricity

- Net Electrical Generation

- Net Electrical Energy for Load 
- Peak Load Electricity Demand - Net Capability

- Costs of Fuel for the Generation of Electricity

- Prices of Electricity to Retail Customers

Two of the original titles, "Deliveries", and "Price", have been changed to eliminate confusion as to what is being reported. The term "deliveries" is used twice in the publication; the first for the deliveries of raw materials to the utility: the second for deliveries of electricity from the utility. This confusion can be eliminated by changing the title "Deliveries" to "Receipte." The term "price" is also used twice; once for the cost of raw materials to the utility; the second for the price of electricity to the customer. We recommend that "Price" of raw materials be changed to "Cost" to reflect more accuratcly the economic process invulved.

\section{Ending Materials}

The current version of the publication includes four items which, for purposes of discussion, are referred to here as ending materials. These items include:

- Glossary of Terms Used in the Publication

- Table Depicting Degree Days for the Period Covered by the Data

- Thermal Conversion Tahle.

- Reader's Cumment Form

We feel that the glossary provided is extremely useful and would be retained. However, the data on degree days, which are provided as an appendix to the publication, does not directly relate to the data included in the publication and seems superfluous. If this perception is not rnrrect, then an explanation of the data's usefulness vis. a. vis. the entire publication should be indicated in the introduction.

The Thermal Conversion Table, which has been provided is seen as helpful to the user. However, if it is to be retained, a Btu to watt conversion formula should be included. 
The Reader's Comment Form provides a conduit for reader response and the publication section provides a bibliography for the reader. We recommend retaining these items and expanding the bibliography as additional appropriate publications are identified.

\section{Graph and Table Ordering:}

In this section we review and make recommendations for improving the order in which graphs and tables have been placed in the current version of the publication. Included in this section are discussions on National Electric Reliability Council (NERC) and census region and state data ordering and aggregate to disaggregate ordering.

\section{NERC and Census Region Data Ordering}

Five of the current chapters of the EPM - Stocks of Fuel for the Generation of Electricity, Receipts of Fuel for the Generation of Electricity, Consumption of Fuels for the Generation of Electricity, Net Electrical Generation, and Cost of Fuels for: the Generation of Electricity - have data aggregated by both NERC region and census region and state. The current EPM places census region and state tables first within each chapter and section, United States summary graphs (U.S. Totals) second, and NERC tables and graphs third. Although our discussion of the necessity of census region tables occurs later in the report, we will assume for the purpose of critiquing data ordering, that future issues of the EPM will contain these data. We recommend that total United States tables and graphs be placed first within each chapter or section, followed by census region and state tables, and finally by NERC tables and graphs. There are two reasons for this ordering. The first is to conform to the statistical convention that totals should be placed first, followed by supporting data in a descending order of disaggregation. By placing the totals information first, the reader is given an overview of the data and can then proceed logically to whatever level of specificity required. The second reason for this recommendation is a cosmetic consideration. The census region and NERC tables disaggregate the same totals differently and thereby complement each other. The reason for placing the 
NERC tables after the census region and state tables is that the NERC tables are directly followed by. nine graphs. If NERC data precede census data, the tables will be separated by these graphs and the chapter will lose its continuity. The placement of the graphs at the end of the chapter or section maintains continuity and improves the readability of the publication.

\section{Aggregate to Disaggregate Ordering}

The majority of data in the Electric Power Monthly is presented in tables and graphs. Therefore, the ordering of tables and graphs is critical to establishing the relationships between data elements and the comparability of data. We have reviewed the current publication and have made recommendations for arhipving logical conoistency in oilerlug.

The current EPM orders the tables and graphs in a progression from disaggregation to aggregation of data within the two geographic aseas (NERC and census region and state). An example of this progression is provided within the Net Generation chapter:

CHAPTER: NET GENERATION

Disaggregation: By fue1. snirse and seneue region and state Summary: By census region and state

Disaggregation: By fuel source and NERC region Summary: By NERC region

This ordering is confusing. The first table in the Net Generation chapter is "Electric Utility Generation by Fuel Source, Census Region and State" and gives data for generation using hydrnelestric power and coal, followed by oil and gas, nuclear and other. The sumary of thcoc data, "Total Generation", appears seven pages later. Although, in some sense this order is logical, it lacks clarity: the reader is unable to establish a perspective from which to approach the data. Additionally, the placement of graphs behind each table causes further confusion to the reader.

We recommend that the tables be reordered in a descending progression of disaggregation and that a new table be added. The recommended order 
for the chapter on the Net Generation is as follows:

CHAPTER: NET GENERATION

Aggregation: U.S. total by fuel source

Summary: By census region and state

Disaggretation: By fuel source, census region and state

Summary: By NERC region

Disaggregation: By fuel source, NERC region

This descending progression is clear and allows the reader to follow the, data to the level of specificity required.

In some chapters where measurement units are not comparable, such as the chapter on consumption, which measures data in barrels, short tons, and cubic feet, it will not be possible to create a single aggregated table and graph at the beginning of the chapter. In these chapters, the tables should be divided into sections, i.e., Coal, Oil, and Gas, and within each section the census region tables and NERC tables placed in order. Additionally, we recommend that when two or more graphs have a relationship to two or more tables, that the tables be separated into sections. In Net Generation the tables and graphs would be ordered as follows:

CHAPTER: NET GENERATION

Aggregate: U.S. total by fuel source

Table: U.S. total by fuel source

Graph: U.S. total by fuel source

Summary: By census region and state

Disaggregate: By fuel source

Table: Coal and gas

Table: Hydroelectric and oil

Table: Nuclear and other

Summary: Ry NFRC region

Disaggregate: By fuel source

Table: Coal and gas

Table: Hydroelectric and oil

Table: Nuclear and oil

Graphs: NERC graphs

We recommend the EPM be reorganized in this manner. 


\section{Graph and Table Comparability}

It is imperative that comparisons between tables and graphs be accurate. Too often within the EPM data in tables which are measured in megawatts, for example, are not adequately depicted in the graphs because increments have not been made comparable to those in the tables. Whenever it is possible, we believe that measures should be standardized. However, we understand that graphic scales cannot accommodate large numbers which of ten appear in the tables. It is important that the representation of figures, measured in one increment, be properly depicted on graphs which are labeled with the proper comparable increment. Hence, if it is necessary to vary the table and graphic increments, say between megawatts and gigawatts, insure that comparability is accurate.

An example of this kind of problem can be seen in one of the table/graph comparisons in the EPM. In the deliveries section of the EPM, a table measure is in millions of cubic feet of gas $(3,175)$, leading the reader to conclude that for the particular NERC region in question, that 3,175 million cublc feet of gas had been delivered. However, the graphic increment is stated in units of $2,4,6$ and 8 (million cuhir feet). The graph, therefore, indicates that 3,175,000 cubic feet of gas was delivered, not 3,175,000,000 subic feet. Conocquently, the graph is off by a factor of 1,000 .

This example is meant to be representative of similar problems which arise occasionally in the text, and which detract from the accuracy needed in a sophisticated publication surh as the EPM.

Terms, especially those dealing with measurements, should be standardized. Coal is measured in tons in some chapters and short tons in others. Although this is the most obvious inconsistency, special attention should be paid to the terms within the EPM.

In the section of the EPM which deals with NERC regional consumption of coal, uil and gas, the graphs used to depict the data in the various tables 
are misleading. If we look closely at the graphs in this section we see that in each instance, tons of coal, barrels of oil, and cubic feet of gas are directly compared. Moreover, we see that the reader is asked to assume a direct relationship between the three fuel types and the measurement units used. As an alternative, we suggest separating the graphs into three categories according to the type of fuel used for generation gas, oil or coal.

Occasionally, data are not graphed or are so unclear as to make it extremely difficult to discern where they are graphed. An example of this problem can be seen in the consumption section where there does not seem to be a graph reflecting data for gas turbine-internal combustion.

Some graphs show figures which seem to approximate the sections in tables labeled "steam", but no footnotes or explanations defining the bounds of the graph are offered - only a reference to gas consumption which is also the title of the table. The table itself is separated into two sections, but there do not appear to be two appropriately labeled graphs to compare with the sections. The problem which this observation poses, if it is accurate, is that all sections dealing with a separation of data on steam and gas turbine-internal combustion figures manifest the same omissions. Special attention should be paid to NERC regions in this regard, as there is no distinction between steam and gas turbine-internal combustion data in any of the graphs. Indeed, should the graphs actually represent totals information, then indications to that extent should be made in the Chapter Highlights section of this publication. To uncomplicate the situation substantially, we suggest that those tables dealing with both steam and gas turbine-internal combustion be broken down into two separate tables with graphs for each of them. 


\section{Cosmetic Review}

In this section we review and make recommendations for improving the format and graphic representations included in the current version of the EPM. These comments reflect only those issues which pertain to the publication in general. More specific recommendations for improving graphs and tables are made in subsequent chapters of this report. The sections covered in this discussion include:

- The Cover

- Chapter Highlight Pages

- Running Heads

- Type

The Cover

The cover of the current Electric Power Monthly contains the following information: agency number, agency name, title and data of publication, the DOE seal and a rectangle divided into twelve block drawings of related topics discussed within the text. A review of the cover page revealed that although the overall layout was satisfactory, the present drawings lacked visual impact, a quality we feel is necessary to attract the readers interest. We have incorporated some new drawings to complement some of the present ones (See Exhibit 2). We believe this will help the reader by offering an immediate context for the contents in this publication, thereby generating more interest.

Chapter Highlights

In the current publication, the Chapter Highlights page begins $1 \frac{1}{2}$ inches from the top of a standard $8 \frac{1}{2} \times 11$ page, with a $2 \frac{1}{2}$ inch left margin. The numbered title (set in 14 point bold type) begins flush with the left margin. The text begins three spaces below the title (set in 11 point regular type). A review of the Chapter Highlights page revealed that the overall look was too sparse. 'l'he purpose of this page is to "highlight" specific information covered within the section of the publication, 


\section{DOEJEIA-0226 (80/01) U.S. Department of Energy}

Energy Information Administration

Assistant Administrator for

Energy Data Operations

Office of Coal and Electric Power Statistics

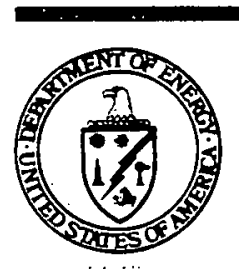

Electric

Power

Monthly

\section{January 1980}

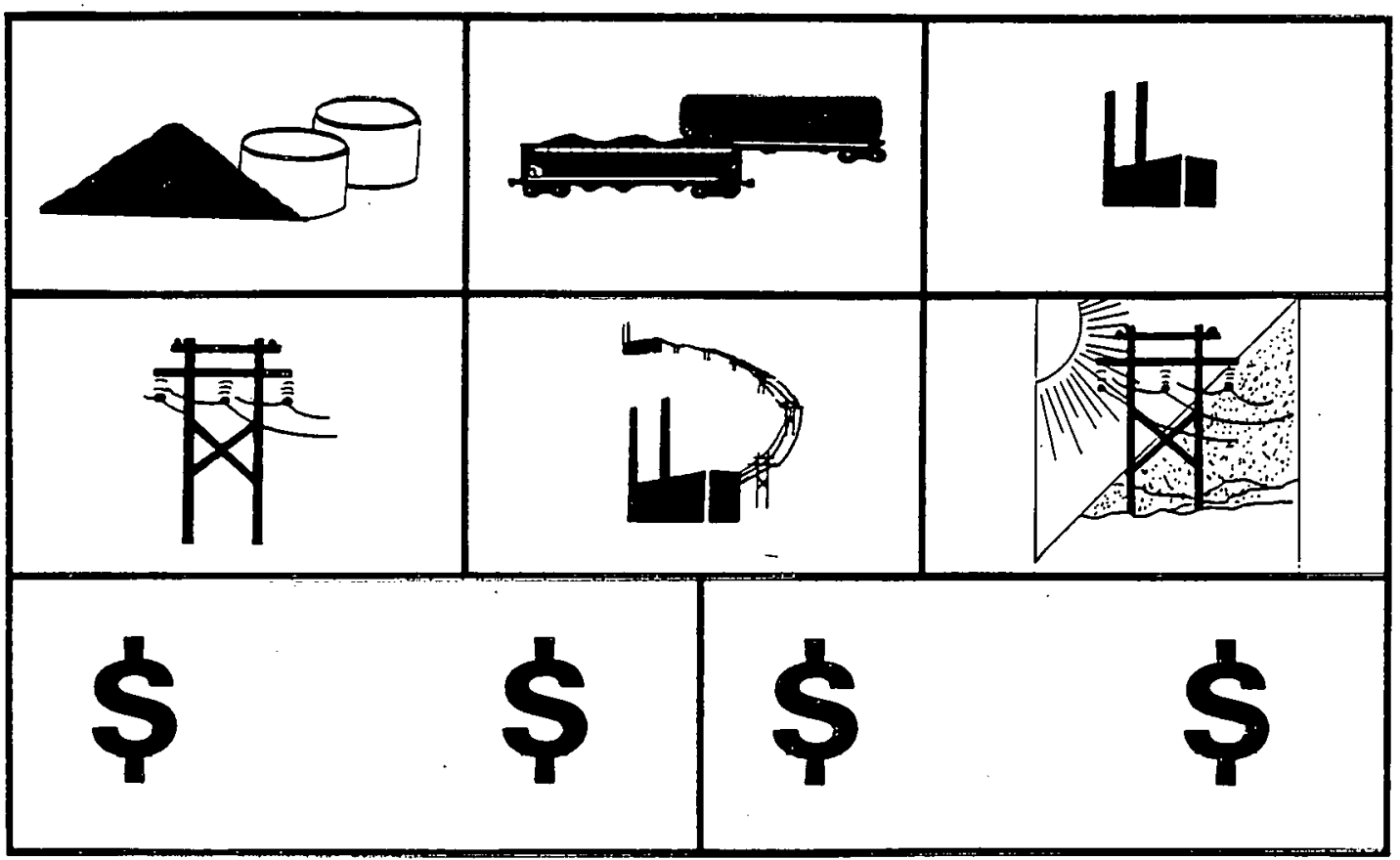

Exhibit 2. Recommended Cover for the Electric Power Monthly 
in a brief and concise manner. The following alterations were made to fulfill this purpose (See Exhibit 3). The first line of the page reads, VOLIMETRIC INFORMATION, flush on the left margin (set in 18 point bold type). The second line is the chapter number and title, beginning two spaces below the first line. The text begins three spaces below the chapter title (set in 11 point regular type). The body of the text has remained the same but has been moved to the left and the lines lengthened to achieve a more contemporary look. Exhibit 4 shows a highlights page without the Volumetric Information head. We believe these alterations will greatly enhance the overall look of the highlights as well as the slgniflcance of this page.

Running Heads

A publication such as the Electric Power Monthly consists primarily of tables and graphs and has very little accompanying text to orient the reader. In the current EPM, running heads were noted on the tops of pages within the chapters (with the exception of the Chapter Highlights page). We agree with this practice; however, the current words selected for the running heads were not consistently succinct. By selecting key words from the revised chapter title, we believe that the running head will better serve the purpose as a signpost for the reader, indicating immediately the subject of each page.

Typefaces

The selection of type fonts and sizes used for the Electric Power Monthly presents the data clearly and we recommend that the type used in the legends and axis conform to the style used in the tables and graphs. 


\title{
Volumetric Information
}

\author{
1. Stocks of Fuel for \\ the Generation of Electricity
}

Coal stocks as of February 1, 1980 were 158.9 million tons compared with 159.9 million tons on January 1, 1980; stocks increased 32.3 percent above the February 1,1979 stocks of 120.1 million tons.'

Oil stocks at steam plants on February 1 were 114.0 million barrels compared with 111.1 million the previous month. At gas turbine and internal combustion plants, February 1 . stocks were 19.6 million barrels compared with 20.3 million barrels on January 1, 1980. Heavy oil stocks as of February 1,1980 were 101.6 million barrels. For plants using light oil, February 1 stocks were 32.0 million barrels.

' includes petroleum coke.

Source - FPC Form 4

Exhibit 3. Recommended Format for the First Chapter Highlights Page of Volumetric Information 


\section{Consumption of Fuels for the Generation of Electricity}

During January 1980 , utilities consumed 50.4 million tons of coal compared with 47.1 million tons the previous month.' January 1980 consumption increased 7.4 percent from the January 1979 figures. The largest consumer of coal in January 1980 was the East Central Reliability Coordination Agreement (ECAR), which consumed 15.0 million tons, or 29.8 percent of all coal consumed in the U.S.

Steam, gas turbine, and internal combustion p!ants cunsumed a total of 43.3 million barrels of oil in January 1980 compared with $\mathbf{4 3 . 5}$ million barrels the previous month.' January 1980 oil consumption was 36.8 percent below the January 1878 total. Plants using heavy oil consumed 39.7 million barrels in January 1980. Light oil consumption amounted to 3.6 million barrels in January. The largest consumer of oil in January 1980 was the Northeast Power Coordinating Council (NPCC) (U.S.) which consumed 14.5 million barrels, or 33.5 percent of all the oil consumed in the United States during January 1980.

During January 1980 , steam plants consumed 256.3 billion feet of natural gas, up from 238.3 billion the proviouo montr. Gas turbine and internal combustion plants consumed 20.5 billion cubic feot, compared with 21.0 billion in December 1979. Total gas consumption for January was an increase of 21.1 percent from the 1979 figures. The largest consumer of natural gas was the Southwest Power Pool (SWPP). which consumed 106.0 billion cubic feet in January 1980 , or 38.3 percent of the total gas consumption. The Electric Reliability Council of Texas (ERCOT) was close behind the SWPP in gas consumption by consuming 80.9 billion cubic feet, or 29.2 percent of the total gas conoumption.

'Includes petroleum coke.

Does not include petroleum coke.

Source - FPC Form 4

Exhibit 4. Recommended Format for a Chapter Highlights Page 


\section{Review of Tables}

The following section includes a review of substantive issues and cosmetic issues pertaining to the data tables contained in the current version of the publication.

\section{Substantive Review}

The following is a review of the information contained in the data tables included in the current version of the EPM and our recommendations for making improvements, The following topics are discussed in this section:

- Overall Table Review

- Tabular Presentation

- Problems with Specific Tables

\section{Overall Table Review}

Our review of tables has concentrated on what data is currently missing and what data can be eliminated as redundant or unnecessary to the purpose of the publication. Additionally, we have reviewed each table within the EPM for comparability and clarity of presentation.

Although most of the tables have included data for Alaska and Hawaii, a significant number present only the contiguous 48 states. In order to make each table and total comparable we recommend that the data from these two states be added where missing. This will eliminate any inconsistency in geographic coverage of tables. 
As stated previously in this report, we recommend the inclusion of totals and summary tables wherever possible in order to give the reader an immediate perspective on the chapter or aggregation of data. Examples of these new tables are:

Stocks of Fuel for the Generation of Electricity

- Stocks of Coal, Total U.S.

- Srocks of 011, Toeal U.s.

Receipts of Fuel for the Generation of Electricity

- Receipts of Coal; Total U.S.

- Receipts of Gas, Total U.S.

- Receipts of Oil, Total U.S.

Consumption of Fuel for the Generation of Electricity

- Consumption of Coal, Total U.S.

- Consumption of Gas, Total U.S.

- Coneumption of Oil, Total U.S.

Net Electrical Generation

- Electrical Generation by Fuel Type, Total U.S.

Net Electrical Energy for Load

- Net Electrical Energy for Load, Total U.S. 
Peak Load Electricity Demand - Net Capability

- Peak Load and Net Capability data, Total U.S.

\section{Cost of Fuels}

- Cost of Coal, U.S. Average.

- Cost of Heavy Oil, U.S. Average

- Cost of Light Oil, U.S. Average

- Cost of Gas, U.S. Average

Retail Electricity consists of only one table and as such does not require a summary table.

Each of these tables would then be followed by a 25 month graph which can occupy the same page, and tables and graphs disaggregating the data by census region and state and NERC region.

Some of the tables in the EPM have data for the current month, the previous month and the month one year earlier, while others only have data for the current and previous month. (Peak Load Electrical Demand - Net Capability reports only one month but is exempt from this review due to the amount of data reported and the infeasibility of breaking the five types of information into separate graphs.) This reflects the inconsistency of the data displayed within the chapters. In the "Stocks January 1980 versus December 1979" table, stocks are reported with two columns added for amount change and percent change. The next table duplicates the January 1980 data but compares it to January 1979 and reports the amount and percent change. Other chapters report only the data for the three months and omit percent and amount change data.

To be consistent, one standard for data display should be adopted. Ideal$1 y$, the previous month and the month during the prior year should both be compared to the current month and amount changes and percent changes reported; luwever, as this will add more tables to the already significant number, we recommend that either the current month with previous month, amount and percent change, or the current month, month one year earlier, 
amount and percent comparison be adopted throughout the publication. The selection of either one is dependent on which would be more useful to the reader. The data for the month not selected will still be included in an accompanying graph and is not lost.

Another inconsistency occurs within the Receipts section. These tables have columns for "Numbers Reporting - Companies/Plants" which are not duplicated elsewhere within the publication. If these data are important they should be duplicated in every other table. If not of major importance or unavailable from other forms, the columns should be eliminated from all tables.

There are two basic types of tables in the EPM - NERC regions and census region and state. Within each chapter, each data aggregate is duplicated and disaggregated into either the nine NERC regions or the 48 or 50 states. Although the two exist independently, upon review we question the actual necessity of the census region and state tables. The disaggregation of electric utility data into these areas creates some inconsistencies and raises questions about their accuracy. The major inconsistencies are that the NERC regions are always graphed while the census regions are not and that some chapters (Net Electrical Energy for Load, and Peak Load Electrical Demand - Net Capability) do not include a disaggregation by census reylun and slate. Questions of dicuracy oceur duc to the nature of electric utility generation. The NERC regions consist of networks of electric utility systems throughout the United States and Canada. The majority of these regions divides some states and encompasses parts of Canada. It is therefore difficult not to question data attributed to states such as Missouri, Mississippi, Texas, Wisconsin, Wyoming, North Dakota, New Mexico, Kentucky, Virginia, and Pennsylvania, all of which 20 percent of the United States - are divided between regions. If there is a procedure for separating these data accurately, or, if not, the biases involved in the reporting of the state data should be explained within the publication. Due to these factors, and the nature of electric utilities, we recommend that OEDO cunsider the elimination of census region and state tables. 
Some confusion arises within the Consumption chapter on the gas and oil census region and state tables. The consumption of both of these fuel sources is divided by steam and gas turbine - internal combustion. These tables lack a totals column for each of the line cells. If this division is important, the 12 months prior column can be eliminated, thus allowing this column.

\section{Tabular Presentation}

Within each table the title, headnote, boxheads, line captions, cells and endnotes should uniquely identify each datum presented. We have reviewed each of these components together and separately to see if this criteria has been met.

Within the Electric Power Monthly each title should supply the following information:

- Energy Function (Stocks, Net Generation)

- Energy Source (Coal)

- Energy Function Adverbial Phrase (for the Generation of Electricity)

- Geographic Level of Aggregation

- Reported Time Interval (January 1979)

- Units (Although properly classified as a headnote, within the EPM this is a necessary part of the title and will be considered as such.)

When put in this order, titles consistently and clearly identify the data contained within the table, whether read independently of the chapter, the EPM or the data itself. (The data coverage, source and footnotes which are necessary for comparability are discussed later in this report.) The current titles of the EPM identify the data, but only within the context of the EPM. An example of this is the title, "Stocks of Coal by Census Region and State, January 1980." Although it is assumed that these stocks are for the generation of electricity, out of the context of the 
EPM there is nothing that separates these stocks from those of commercial stockyards. "Stocks of Oil by Census Region and State" does not distinguish utility stocks from those to be used for home heating. The energy function adverbial phrase is critical to uniquely identify the data.

Although the components of the title can be ordered differently, for consistency we recommend that the title syntactic structure in Exhibit 5 be adopted throughout the EPM.

Although the title identifies the data within a table, comparability is usually achieved when it is combined with informative endnotes. Where necessary, these endnotes should include biases in reporting of data, data source and the coverage of the data source. Although the difference in coverage between the forms is reported on the Scope of Publication page, we feel there is enough variance between the coverage -4 percent to 29 percent - to warrant placing the coverage under each table. As this may be impractical due to space limitations, it can be placed once on each page. Although this recommendation does not conform to EIA standards and may not be feasible with the current computer graphics capabilities, we feel this note is important. It will eliminate the need for the reader to remember correct attribution while trying to compare statistics and therefore simplify the reading of the publication. The Form 4 note should read "Source - Federal Power Commissioir Foril 4: All electidi ulililies whlh generating plants, accounting for 100 percent of total electric utility generation," and the other source notes should follow this format.

Page. space limitations are an inhibiting factor in achieving comparability. The current EPM has very few footnotes and is brief in others. Ideally, all biases should be reported, all terms defined, and all major increases or decreases explained for each table in the publication. Endnotes containing this information would be impractically large and inflexible. We therefore recommend an Explanatory Notes page at the end of each chapter to provide room for this information with a line in each endnote reading "See Explanatory Notes for definitions and other data." Explanatory Notes are used within the Monthly Energy Review and in other publications and 


\begin{tabular}{|c|c|c|c|c|c|}
\hline $\begin{array}{c}\text { Energy } \\
\text { Function }\end{array}$ & $\begin{array}{l}\text { Energy } \\
\text { Source } \\
\end{array}$ & $\begin{array}{r}\text { Energy Function } \\
\text { Adverbial Phrase }\end{array}$ & $\begin{array}{c}\text { Geographic Level of } \\
\text { Aggregation }\end{array}$ & $\begin{array}{c}\text { Reported Time } \\
\text { Interval }\end{array}$ & Units \\
\hline Stocks & $\begin{array}{l}\text { Coal } \\
\text { Gas } \\
0 i 1\end{array}$ & $\begin{array}{l}\text { For the Generation } \\
\text { of Electricity }\end{array}$ & $\begin{array}{l}\text { By Census Region and } \\
\text { State, by NERC Region, } \\
\text { U.S. Total }\end{array}$ & $\begin{array}{l}\text { Jan. } 1980 \text { vs. } \\
\text { Jan. } 1979, \\
\text { Jan. } 1977 \text { - } \\
\text { Jan. } 1980\end{array}$ & $\begin{array}{l}\text { Short Tons } \\
\text { Cubic Feet } \\
\text { Barrel }\end{array}$ \\
\hline Receipts & $\begin{array}{l}\text { Coal } \\
\text { Gas } \\
0 \text { il }\end{array}$ & $"$ & $"$ & $"$ & $"$ \\
\hline Consumption & Coal & $"$ & $"$ & $"$ & " \\
\hline $\begin{array}{l}\text { Net Electrical } \\
\text { Generation }\end{array}$ & $\begin{array}{l}\text { By Fuel Source, } \\
\text { using coal, gas, } \\
\text { etc. }\end{array}$ & $N / A$ & $"$ & $"$ & $\begin{array}{l}\text { Gigawatt- } \\
\text { hours }\end{array}$ \\
\hline $\begin{array}{l}\text { Net Electrical } \\
\text { Energy for Load }\end{array}$ & $N / A$ & $N / A$ & $"$ & $"$ & $"$ \\
\hline $\begin{array}{l}\text { Peak Load } \\
\text { Electrical De- } \\
\text { mand - Net } \\
\text { Capability }\end{array}$ & $N / A$ & $N / A$ & $"$ & $"$ & Megawatts \\
\hline $\cos t$ & $\begin{array}{l}\text { Coal } \\
\text { Oil } \\
\text { Gas }\end{array}$ & $\begin{array}{l}\text { For the Generation } \\
\text { of Electricity }\end{array}$ & " & $"$ & $\begin{array}{l}\text { \$ per Short Ton } \\
\$ \text { per Barrel } \\
\$ \text { per Cubic Foot }\end{array}$ \\
\hline
\end{tabular}

EXHIBIT 5. Syntactic Title Structure 
will eliminate the trade-off between space and comparability. We have included an example of a census region tables and NERC table combining our recommendations for titling and endnotes in Exhibits 6 and 7 .

Our review included the boxheads of each table within the EPM. They conform to EIA standards for formal tables and we agree that this presents the data clearly. In some cases though, the spanners and subspanners become overly complex and confusing. We recommend that no more than three levels of spanners be used on any table to eliminate this problem (Exhibit 8).

Although we agree with the EIA standards for formal tables, to be consistent in our report we must break with them on one point and recommend the consideration of placing totals on the first line caption of each table (Exhibits 9 and 10). This conforms to the standard of aggregation to disaggregation which is found in other recommendations in this report.

In reviewing the cells of each table we found the data to be clearly presented and cannot recommend any changes that would constitute a major improvement over what currently exists.

\section{Cosmetic Review}

The following section includes a review of the format for presenting the data in tabular form. On the whole, the tables within the EPM are graphically clear and little improvement is necessary in their presentation. The use of bold face type to emphasize subtotals and totals within the tables is effective. There are a few inconsistencies within the boxheads that need to be corrected. In some tables the stubs - National Electric Reliability and Census Region and State, in particular - are unequally spaced. This is distracting and simple to correst.

Although the following two suggestions deviate from EIA standards, they 
should be considered as possibilities for improving the presentation of the tables. The first suggestion is the separation of the totals line caption and cell from the rest of the data by a space of two lines. This would further emphasize these figures. The second suggestion is that of placing horizontal lines between regions on the census region and state tables. This would help to divide the material. (These are suggestions and are not major improvements but should be taken into consideration.) 


\section{Stocks - Coal}

Table 2. Stocks of Coal for the Generation of Electricity by Census Region and State, January 1980 versus December 1979 (Thousand Short Tons)

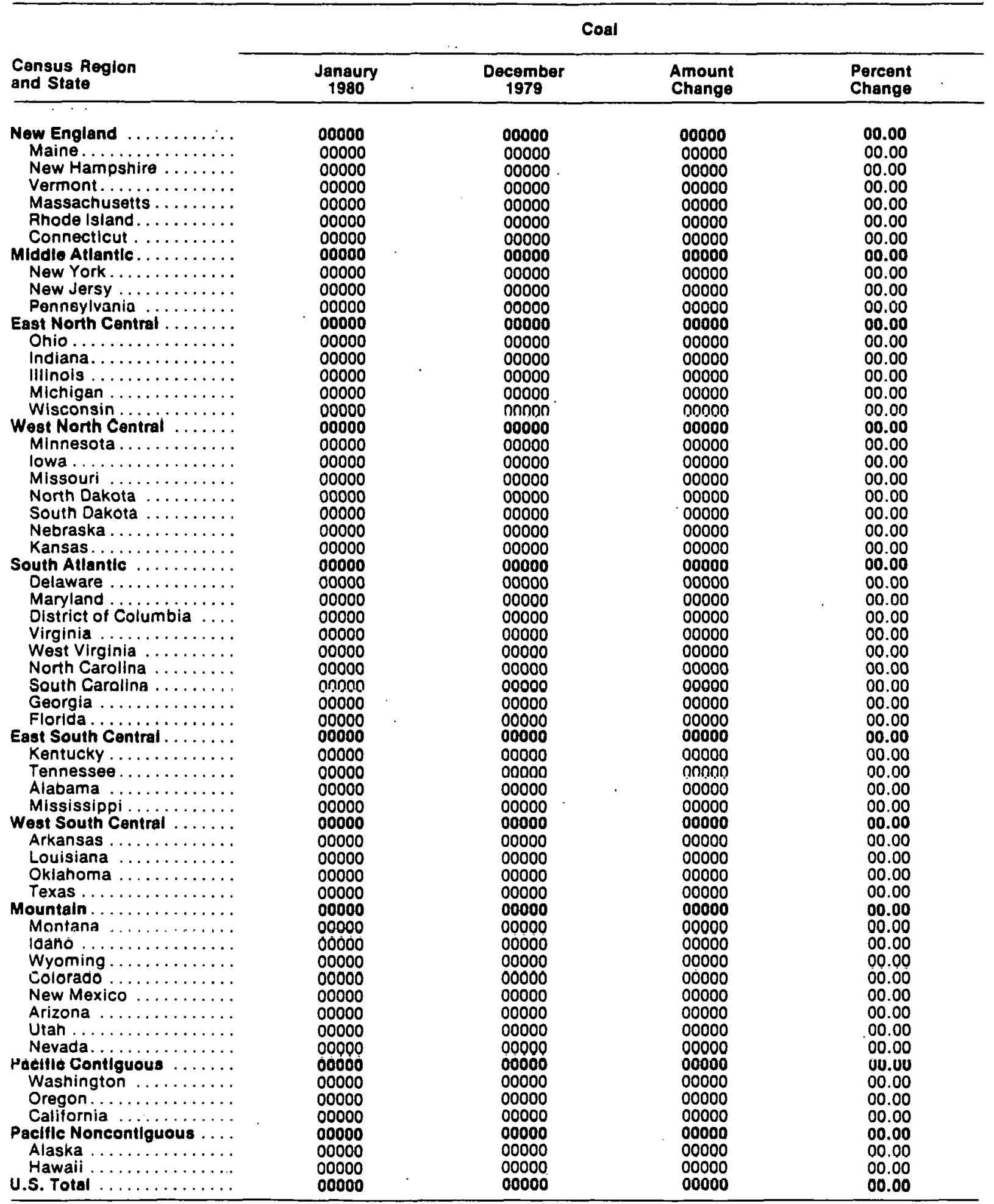

NOTE: Totals may not equal sum of comoonents due to independent rounding. Amount change and percent change calculated before ioundirg.

SCURCE: Federal Power Commission Form 4 reporting all electric utilities with generating plants and accounting for 100 percent of total elecirlc utility generation.

See Exolanatory Notes tor definitions of terms and other data.

Exhibit 6. Table with Recommended Title and Endnotes 


\section{Stocks - Coal}

Table 4. Stocks of Coal for the Generation of Electricity by NERC Region, Alaska and Hawaii, January 1980 versus January 1979 (Thousand Short Tons)

\begin{tabular}{|c|c|c|c|c|}
\hline \multirow{2}{*}{$\begin{array}{l}\text { National Electric } \\
\text { Reliability Council } \\
\text { Region and State }\end{array}$} & \multicolumn{4}{|c|}{ Coal } \\
\hline & $\underset{1980}{\operatorname{January}}$ & 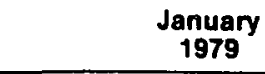 & $\begin{array}{c}\text { Amount } \\
\text { Change }\end{array}$ & $\begin{array}{l}\text { Percent } \\
\text { Change }\end{array}$ \\
\hline 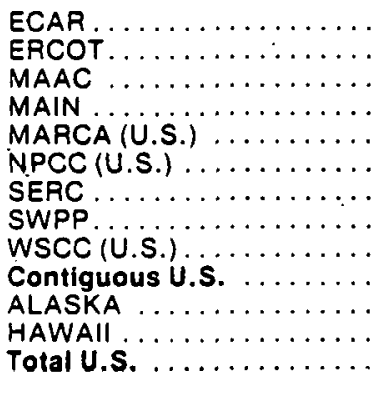 & $\begin{array}{l}00000 \\
00000 \\
00000 \\
00000 \\
00000 \\
00000 \\
00000 \\
00000 \\
00000 \\
00000 \\
00000 \\
00000 \\
00000\end{array}$ & $\begin{array}{l}00000 \\
00000 \\
00000 \\
00000 \\
00000 \\
00000 \\
00000 \\
00000 \\
00000 \\
00000 \\
00000 \\
00000 \\
00000\end{array}$ & $\begin{array}{l}00000 \\
00000 \\
00000 \\
00000 \\
00000 \\
00000 \\
00000 \\
00000 \\
00000 \\
00000 \\
00000 \\
00000 \\
00000\end{array}$ & $\begin{array}{l}00.00 \\
00.00 \\
00.00 \\
00.00 \\
00.00 \\
00.00 \\
00.00 \\
00.00 \\
00.00 \\
00.00 \\
00.00 \\
00.00 \\
00.00\end{array}$ \\
\hline
\end{tabular}

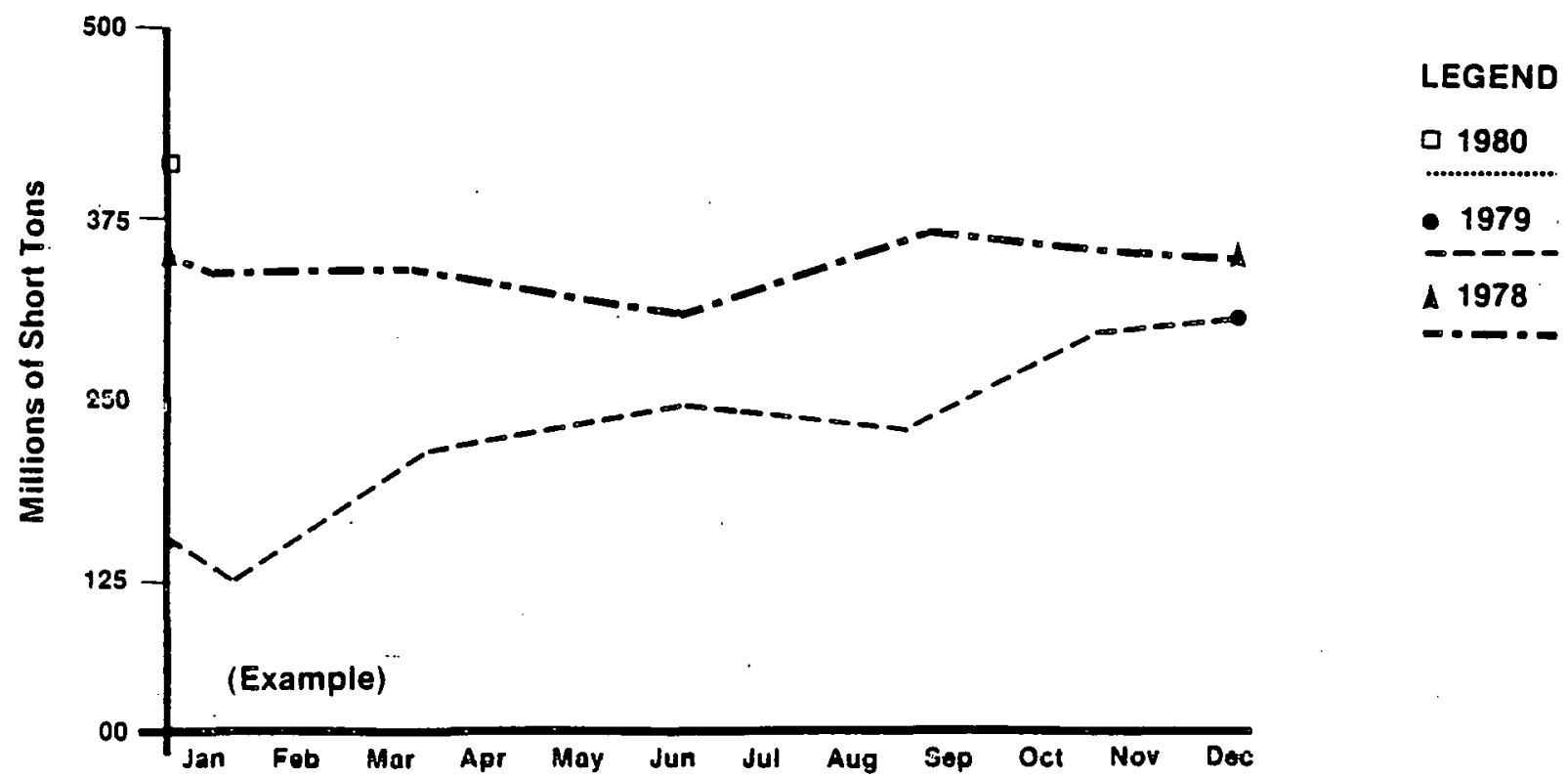

Figure 2. Stocks of Coal for the Generation of Electricity, ECAR Region, January 1978 - January 1980.

NCTE. Toials may no: equal sum of components que 10 ingeoendent rounding. Amount change and percent cnange calculated before Ounainc.

SO :PCE Feceral Power Commission Form 4 reporing all electric utilities with generating plants and accounting for 100 percent of total electric ullily generation.

See Expạnatory Notes to cefinttions of ierms and orher tata.

Exhibit 7. Table and Graph with Recommended Titles and Endnotes 
Costs - Oil

Table 54. Cost of Light Oil, by Type of Purchase, and Census Region and State, December 1979

\begin{tabular}{|c|c|c|c|c|c|c|c|c|c|}
\hline \multirow{3}{*}{$\begin{array}{l}\text { Census Region } \\
\text { and State }\end{array}$} & \multicolumn{6}{|c|}{ Average Cost by Type o } & \multirow{2}{*}{\multicolumn{3}{|c|}{ Total }} \\
\hline & \multicolumn{3}{|c|}{ Contract } & \multicolumn{3}{|c|}{ Spot } & & & \\
\hline & $\begin{array}{l}\text { Quantity. } \\
1000 \text { Bbls }\end{array}$ & $\begin{array}{l}\text { Cents/ } \\
10 \text { Btu }\end{array}$ & $\begin{array}{l}\text { \$ Por } \\
\text { Bbl }\end{array}$ & $\begin{array}{l}\text { Quantity } \\
1000 \text { Bbls }\end{array}$ & $\begin{array}{l}\text { Cents/ } \\
10 \text { Btu }\end{array}$ & $\begin{array}{l}\text { SPer } \\
\text { Bbl }\end{array}$ & $\begin{array}{l}\text { Quantity } \\
1000 \text { Bbis }\end{array}$ & $\begin{array}{l}\text { Cents/ } \\
10 \text { Btu }\end{array}$ & $\begin{array}{l}\text { S Per } \\
\text { Bbl }\end{array}$ \\
\hline 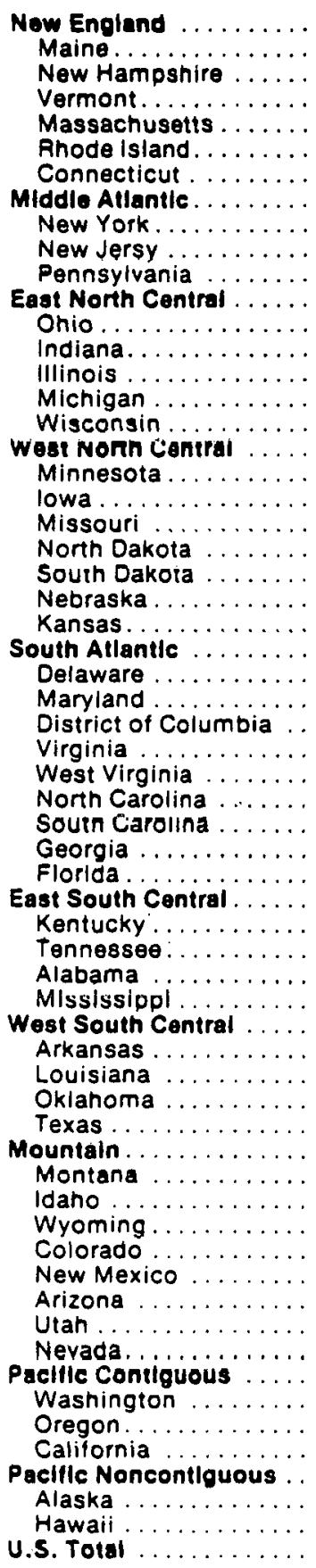 & $\begin{array}{l}00000 \\
00000 \\
00000 \\
00000 \\
00000 \\
00000 \\
00000 \\
00000 \\
00000 \\
00000 \\
00000 \\
00000 \\
00000 \\
00000 \\
00000 \\
00000 \\
00000 \\
00000 \\
00000 \\
00000 \\
00000 \\
00000 \\
00000 \\
00000 \\
00000 \\
00000 \\
00000 \\
00000 \\
00000 \\
00000 \\
00000 \\
00000 \\
00000 \\
00000 \\
00000 \\
00000 \\
00000 \\
00000 \\
00000 \\
00000 \\
00000 \\
00000 \\
00000 \\
00000 \\
00000 \\
00000 \\
00000 \\
00000 \\
00000 \\
00000 \\
00000 \\
00000 \\
00000 \\
00000 \\
00000 \\
00000 \\
00000 \\
00000 \\
00000 \\
00000 \\
00000 \\
00000\end{array}$ & 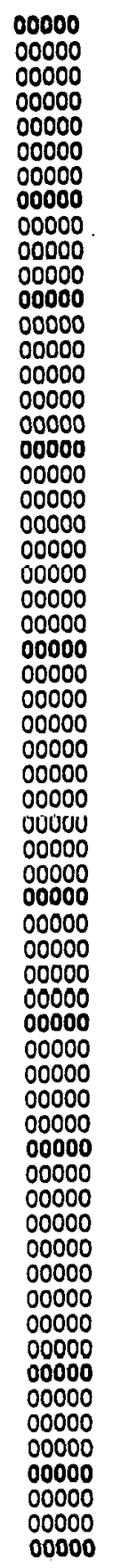 & $\begin{array}{l}00.00 \\
00.00 \\
00.00 \\
00.00 \\
00.00 \\
00.00 \\
00.00 \\
00.00 \\
00.00 \\
00.00 \\
00.00 \\
00.00 \\
00.00 \\
00.00 \\
00.00 \\
00.00 \\
00.00 \\
00.00 \\
00.00 \\
00.00 \\
00.00 \\
00.00 \\
00.00 \\
00.00 \\
00.00 \\
00.00 \\
00.00 \\
00.00 \\
00.00 \\
00.00 \\
00.00 \\
00.00 \\
00.00 \\
00.00 \\
00.00 \\
00.00 \\
00.00 \\
00.00 \\
00.00 \\
00.00 \\
00.00 \\
00.00 \\
00.00 \\
00.00 \\
00.00 \\
00.00 \\
00.00 \\
00.00 \\
00.00 \\
00.00 \\
00.00 \\
00.00 \\
00.00 \\
00.00 \\
00.00 \\
00.00 \\
00.00 \\
00.00 \\
00.00 \\
00.00 \\
00.00 \\
00.00\end{array}$ & $\begin{array}{l}00000 \\
00000 \\
00000 \\
00000 \\
00000 \\
00000 \\
00000 \\
00000 \\
00000 \\
00000 \\
00000 \\
00000 \\
00000 \\
00000 \\
00000 \\
00000 \\
00000 \\
00000 \\
00000 \\
00000 \\
00000 \\
00000 \\
00000 \\
00000 \\
00000 \\
00000 \\
00000 \\
00000 \\
00000 \\
00000 \\
00000 \\
00000 \\
00000 \\
00000 \\
00000 \\
00000 \\
00000 \\
00000 \\
00000 \\
00000 \\
00000 \\
00000 \\
00000 \\
00000 \\
00000 \\
00000 \\
00000 \\
00000 \\
00000 \\
00000 \\
00000 \\
00000 \\
00000 \\
00000 \\
00000 \\
00000 \\
00000 \\
00000 \\
00000 \\
00000 \\
00000 \\
00000\end{array}$ & 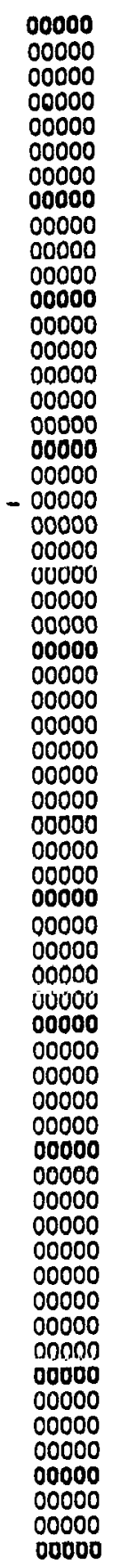 & $\begin{array}{l}00.00 \\
00.00 \\
00.00 \\
00.00 \\
00.00 \\
00.00 \\
00.00 \\
00.00 \\
00.00 \\
00.00 \\
00.00 \\
00.00 \\
00.00 \\
00.00 \\
00.00 \\
00.00 \\
00.00 \\
00.00 \\
00.00 \\
00.00 \\
00.00 \\
00.00 \\
00.00 \\
00.00 \\
00.00 \\
00.00 \\
00.00 \\
00.00 \\
00.00 \\
00.00 \\
00.00 \\
00.00 \\
00.00 \\
00.00 \\
00.00 \\
00.00 \\
00.00 \\
00.00 \\
00.00 \\
00.00 \\
00.00 \\
00.00 \\
00.00 \\
00.00 \\
00.00 \\
00.00 \\
00.00 \\
00.00 \\
00.00 \\
00.00 \\
00.00 \\
00.00 \\
00.00 \\
00.00 \\
00.00 \\
00.00 \\
00.00 \\
00.00 \\
00.00 \\
00.00 \\
00.00 \\
00.00\end{array}$ & $\begin{array}{l}00000 \\
00000 \\
00000 \\
00000 \\
00000 \\
00000 \\
00000 \\
00000 \\
00000 \\
00000 \\
00000 \\
00000 \\
00000 \\
00000 \\
00000 \\
00000 \\
00000 \\
00000 \\
00000 \\
00000 \\
00000 \\
00000 \\
00000 \\
00000 \\
00000 \\
00000 \\
00000 \\
00000 \\
00000 \\
00000 \\
00000 \\
00000 \\
00000 \\
00000 \\
00000 \\
00000 \\
00000 \\
00000 \\
00000 \\
00000 \\
00000 \\
00000 \\
00000 \\
00000 \\
00000 \\
00000 \\
00000 \\
00000 \\
00000 \\
00000 \\
00000 \\
00000 \\
00000 \\
00000 \\
00000 \\
00000 \\
00000 \\
00000 \\
00000 \\
00000 \\
00000 \\
00000\end{array}$ & 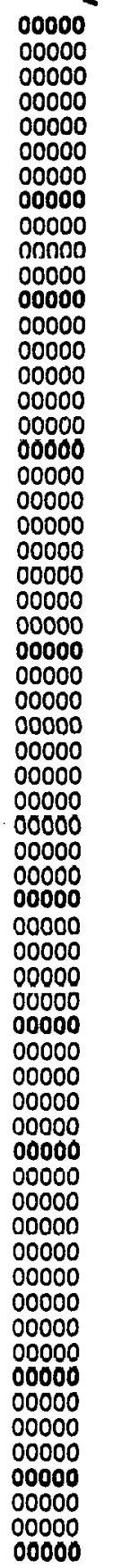 & $\begin{array}{l}00.00 \\
00.00 \\
00.00 \\
00.00 \\
00.00 \\
00.00 \\
00.00 \\
00.00 \\
00.00 \\
00.00 \\
00.00 \\
00.00 \\
00.00 \\
00.00 \\
00.00 \\
00.00 \\
00.00 \\
00.00 \\
00.00 \\
00.00 \\
00.00 \\
00.00 \\
00.00 \\
00.00 \\
00.00 \\
00.00 \\
00.00 \\
00.00 \\
00.00 \\
00.00 \\
00.00 \\
00.00 \\
00.00 \\
00.00 \\
00.00 \\
00.00 \\
00.00 \\
00.00 \\
00.00 \\
00.00 \\
00.00 \\
00.00 \\
00.00 \\
00.00 \\
00.00 \\
00.00 \\
00.00 \\
00.00 \\
00.00 \\
00.00 \\
00.00 \\
00.00 \\
00.00 \\
00.00 \\
00.00 \\
00.00 \\
00.00 \\
00.00 \\
00.00 \\
00.00 \\
00.00 \\
00.00\end{array}$ \\
\hline
\end{tabular}

NOTE To:als may not eoual sum of comoonents due to independent rounding. Amoun! change and percent cnange calculated defore - Sunotse.

SE.PCCE. Eeceial Poiver Cormission Form 4 reporing ail electrıc uilities with generatıng plants and accouning for 100 oercent of total Eleciric stitity generation.

Sez Ercianatory Nc:es to: cefini:?cn ol terms ana cther data.

Exhibit 8, Table with Revised Spanner and Subspanner 
Consumption - Coal

Table 20. Consumption of Coal for the Generation of Electricity by Census Region and State, January 1980, December 1979, January 1979 (Thousand Short Tons)

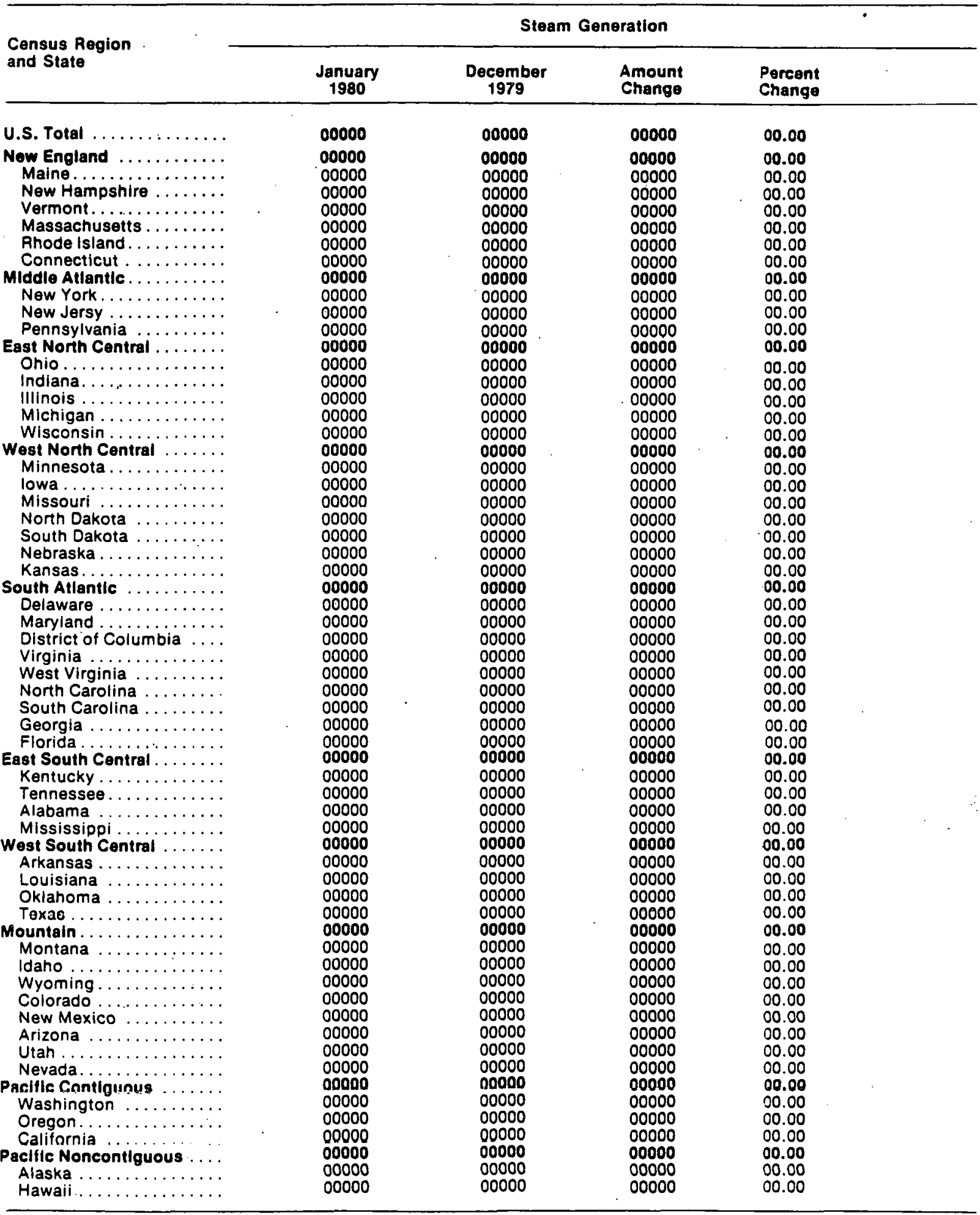

NOTE: To:als may not equal sum of components due to independent rounoing. Amount change and oercent cnange calculated betore curiding

SOURCE: Feceral Fower Commission Form 4 feoorting all electric uitities with generating plants and accounting fcr 100 percent of total electicic uthtity generation.

ה.P. Frnlanathy Notes tor dofinition of torms and othor data.

Exhibit 9. Table with Total as first Line Caption 


\section{Stocks - Oil}

Table 9. Stocks of Oil for the Generation of Electricity by NERC Region, Alaska and Hawaii, January 1980 versus January 1979 (Thousand Barrels)

\begin{tabular}{|c|c|c|c|c|}
\hline \multirow{2}{*}{$\begin{array}{l}\text { National Electric } \\
\text { Rellability Council } \\
\text { Region and State }\end{array}$} & \multicolumn{4}{|c|}{ Oil } \\
\hline & $\begin{array}{c}\text { January } \\
1980\end{array}$ & $\underset{1979}{\text { January }}$ & $\begin{array}{c}\text { Amount } \\
\text { Change }\end{array}$ & $\begin{array}{l}\text { Percent } \\
\text { Change }\end{array}$ \\
\hline Total U.S. . . . . . . . . . & 00000 & 00000 & 00000 & 00.00 \\
\hline 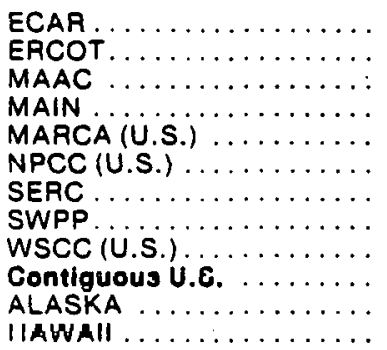 & $\begin{array}{l}00000 \\
00000 \\
00000 \\
00000 \\
00000 \\
00000 \\
00000 \\
00000 \\
00000 \\
00000 \\
00000 \\
00000\end{array}$ & $\begin{array}{l}00000 \\
00000 \\
00000 \\
00000 \\
00000 \\
00000 \\
00000 \\
00000 \\
00000 \\
00000 \\
00000 \\
00000\end{array}$ & $\begin{array}{l}00000 \\
00000 \\
00000 \\
00000 \\
00000 \\
00000 \\
00000 \\
00000 \\
00000 \\
00000 \\
00000 \\
00000\end{array}$ & $\begin{array}{l}00.00 \\
00.00 \\
00.00 \\
00.00 \\
00.00 \\
00.00 \\
00.00 \\
00.00 \\
00.00 \\
00.00 \\
00.00 \\
00.00\end{array}$ \\
\hline
\end{tabular}

Table 10. Stocks of Oil for the Generation of Electricity by NERC Region, Alaska and Hawaii. January 1980 versus Dereamhar 1979 (Thnısanand Rạrrẹls)

\begin{tabular}{|c|c|c|c|c|}
\hline \multirow{2}{*}{$\begin{array}{l}\text { National Electric } \\
\text { Reliability Councll } \\
\text { Region and State }\end{array}$} & \multicolumn{4}{|c|}{ OII } \\
\hline & $\begin{array}{c}\text { Janitary } \\
1980\end{array}$ & $\begin{array}{c}\text { January } \\
1979\end{array}$ & $\begin{array}{c}\text { Amount } \\
\text { Change }\end{array}$ & $\begin{array}{l}\text { Percont } \\
\text { Change }\end{array}$ \\
\hline Total U.S. . . . . . . . . . . & 00000 & 00000 & 00000 & 00.00 \\
\hline 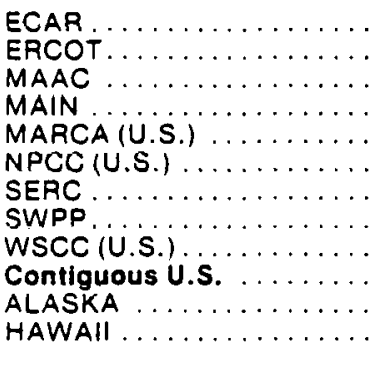 & $\begin{array}{l}00000 \\
00000 \\
00000 \\
00000 \\
00000 \\
00000 \\
00000 \\
00000 \\
00000 \\
00000 \\
00000 \\
00000\end{array}$ & $\begin{array}{l}00000 \\
00000 \\
00000 \\
00000 \\
00000 \\
00000 \\
00000 \\
00000 \\
00000 \\
00000 \\
00000 \\
00000\end{array}$ & $\begin{array}{l}00000 \\
00000 \\
00000 \\
00000 \\
00000 \\
00000 \\
00000 \\
00000 \\
00000 \\
00000 \\
00000 \\
00000\end{array}$ & $\begin{array}{l}00.00 \\
00.00 \\
00.00 \\
00.00 \\
00.00 \\
00.00 \\
00.00 \\
00.00 \\
00.00 \\
00.00 \\
00.00 \\
00.00\end{array}$ \\
\hline
\end{tabular}

NOTE: TOtals may not equal sum of components due to independent rounding. Amount change and percent change caiculated before ouncing.

SOUGCE. Federal Power Comm:ssion Form a reoorting all electric utilities with generating plants and accounting for 100 oercent of total e!ectrc jillity generaticin.

See Exolanaiory Notes tordeinition of ierms and cther gata.

Exhibit 10. Tables with Total as first Line Caption 


\section{Review of Graphs}

\section{Substantive Review}

This section addresses issues regarding the information presented in the graphics and maps included in the current version of the publication. The section contains two parts, an overall review of graphics and maps and a discussion of graphical presentations in the EPM.

\section{Overall Review}

We are concerned that too many pages have been devoted to NERC graphs which, in addition to substantially increasing the size of the publication, may place too much emphasis on one section of data. We have considered increasing the number of graphs on a page from the current two to three or four. The drawbacks to these approaches can be seen in Exhibits 11 and 12. Because neither the length nor the height of the axes can be changed, the graphs have to be greatly reduced to fit more than two on a page. At the required size, clarity can be diminished and the graphs hard to read. Of the two alternatives, four graphs to a page is better graphically but will require the reader to keep turning the publication from the vertical to the horizontal.

Another alternative which should be considered is to combine NERC regions on one graph. For example, if three regions were to be placed on one graph, the definition and clarity of the graph would not be adversely affected. Also, there would be a page reduction in each NERC section of from five pages down to two, or a savings of 60 percent. Of the alternatives available, we suggest employment of the latter, since there is a larger savings in terms of space, and clarity is not sacrificed. Again, this recommendation is depicted in Exhibit 13. 

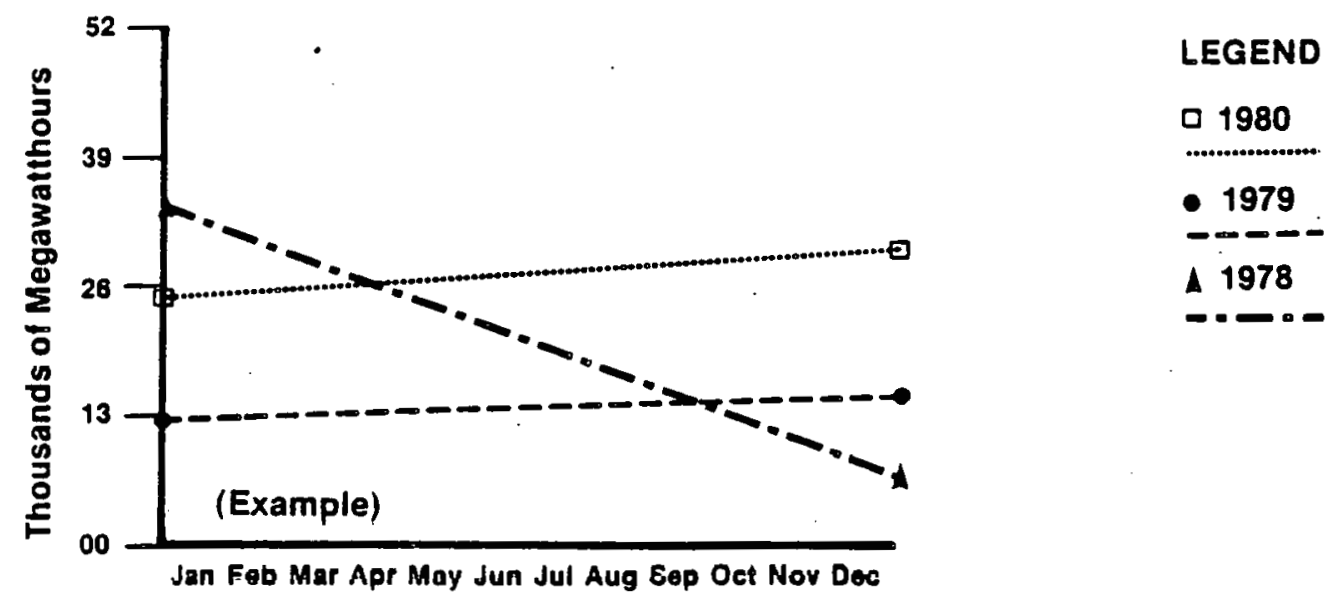

Figure 93. Net Electrical Energy for Load, ERCOT

Region, January 1978 - January 1980.

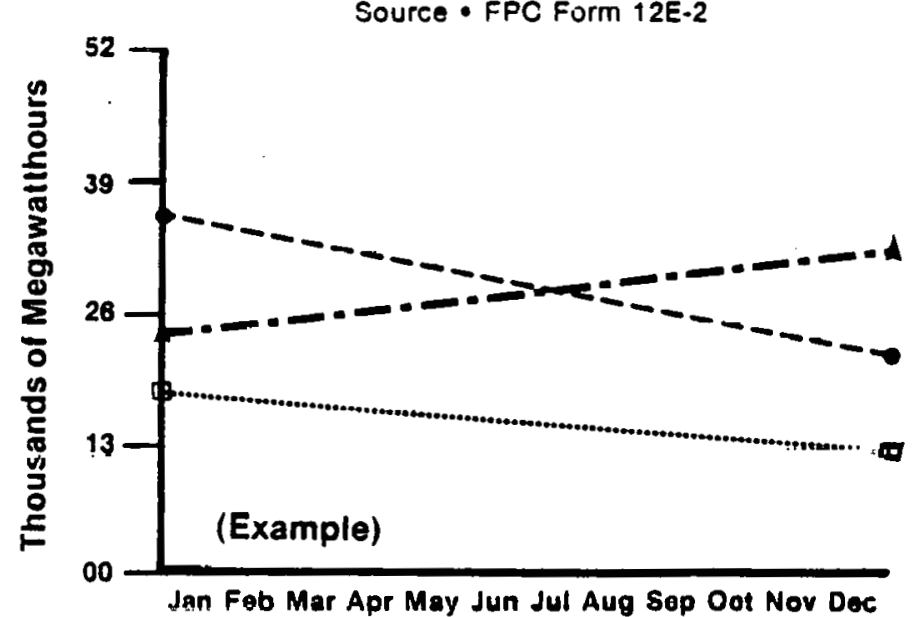

LEGEND

口 1980

..................

- 1979

1978

$-\cdot-\cdot$

Figure 94. Net Electrieal Energy for Luad, MAAC

Region, January 1978 - January 1980

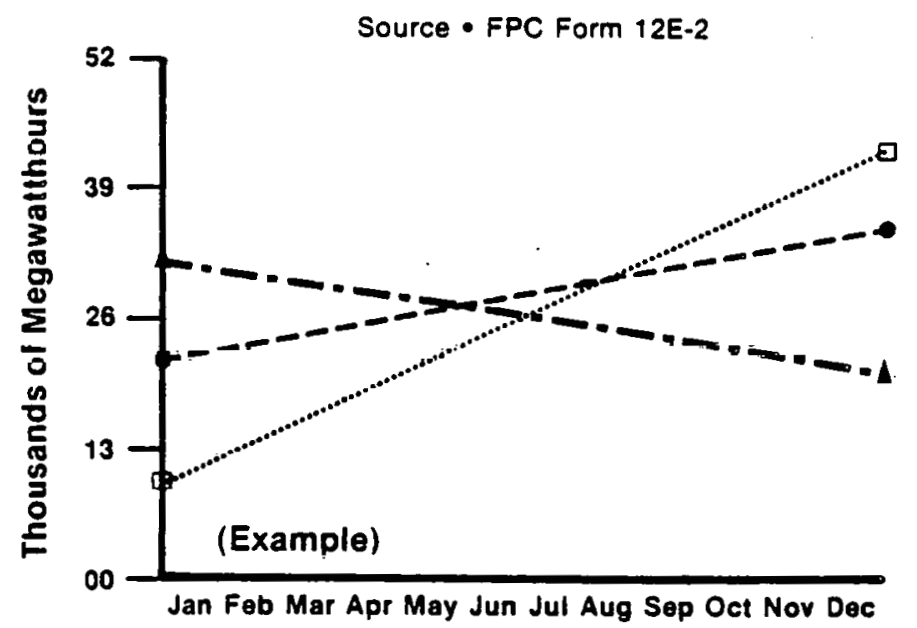

LEGEND

口 1980

1979

$-----$

1978

Figure 95. Net Electrical Energy for Load, MAIN

Region, January 1978 - January 1980

Source - FPC" Form $12 \mathrm{E}-2$

Exhibit 11. Example of Page with Three Graphs 


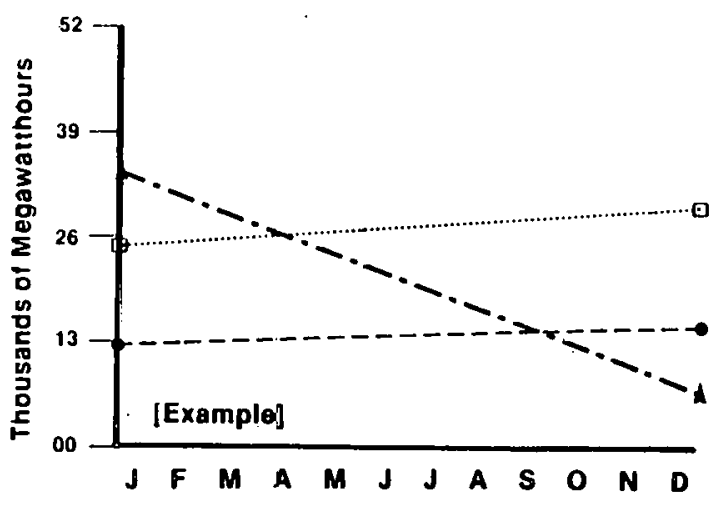

Figure 93. Net Electrical Energy for Load, ERCOT Region, January 1978 - January 1980.

Source - FPC Form 12E-2

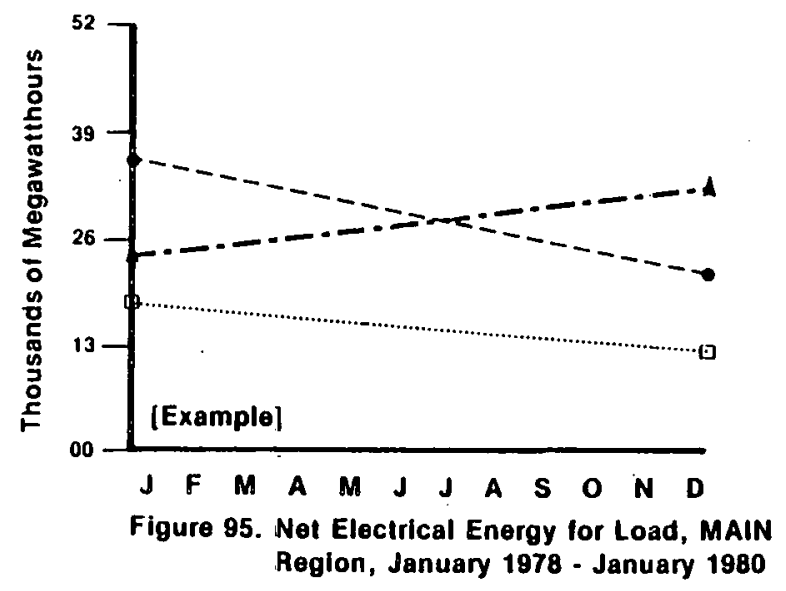

Source - FPC Form 12E-2
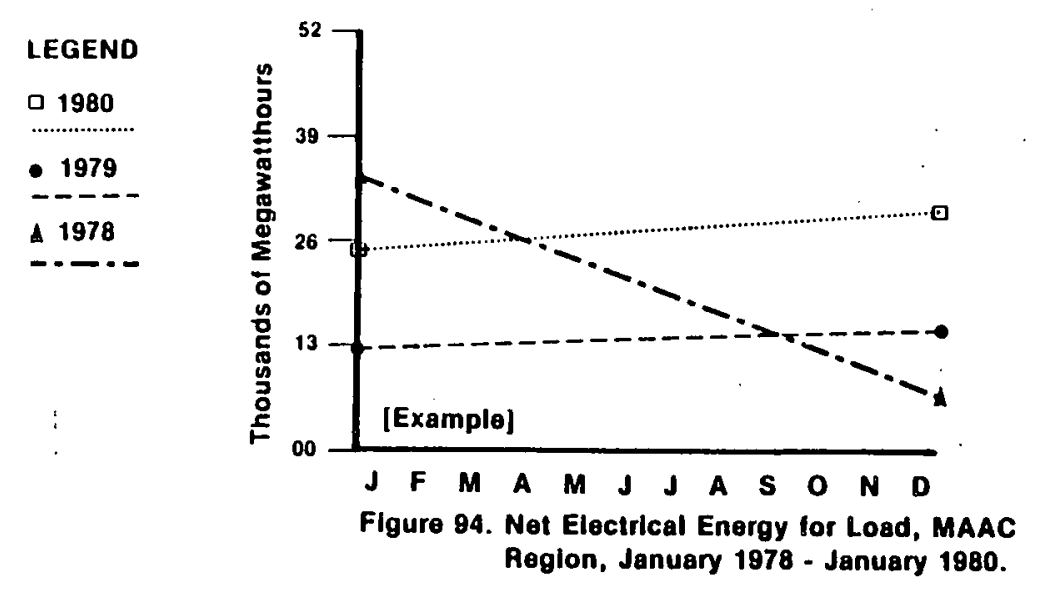

Region, January 1978 - January 1880.

Source - FPC Form 12E-2

LEGEND

व 1980

1979

$\triangle 1978$

$-\cdots-\cdot$

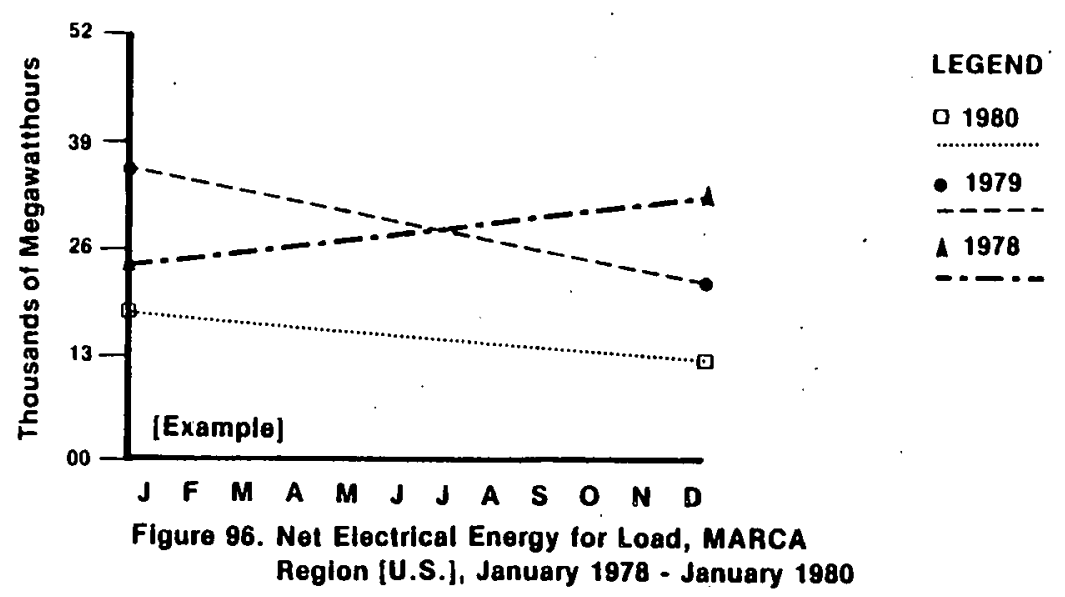

Source - FPC Form 12E-2

\section{Exhibit 12. Example of Page with Four Graphs}


Stocks - Oil

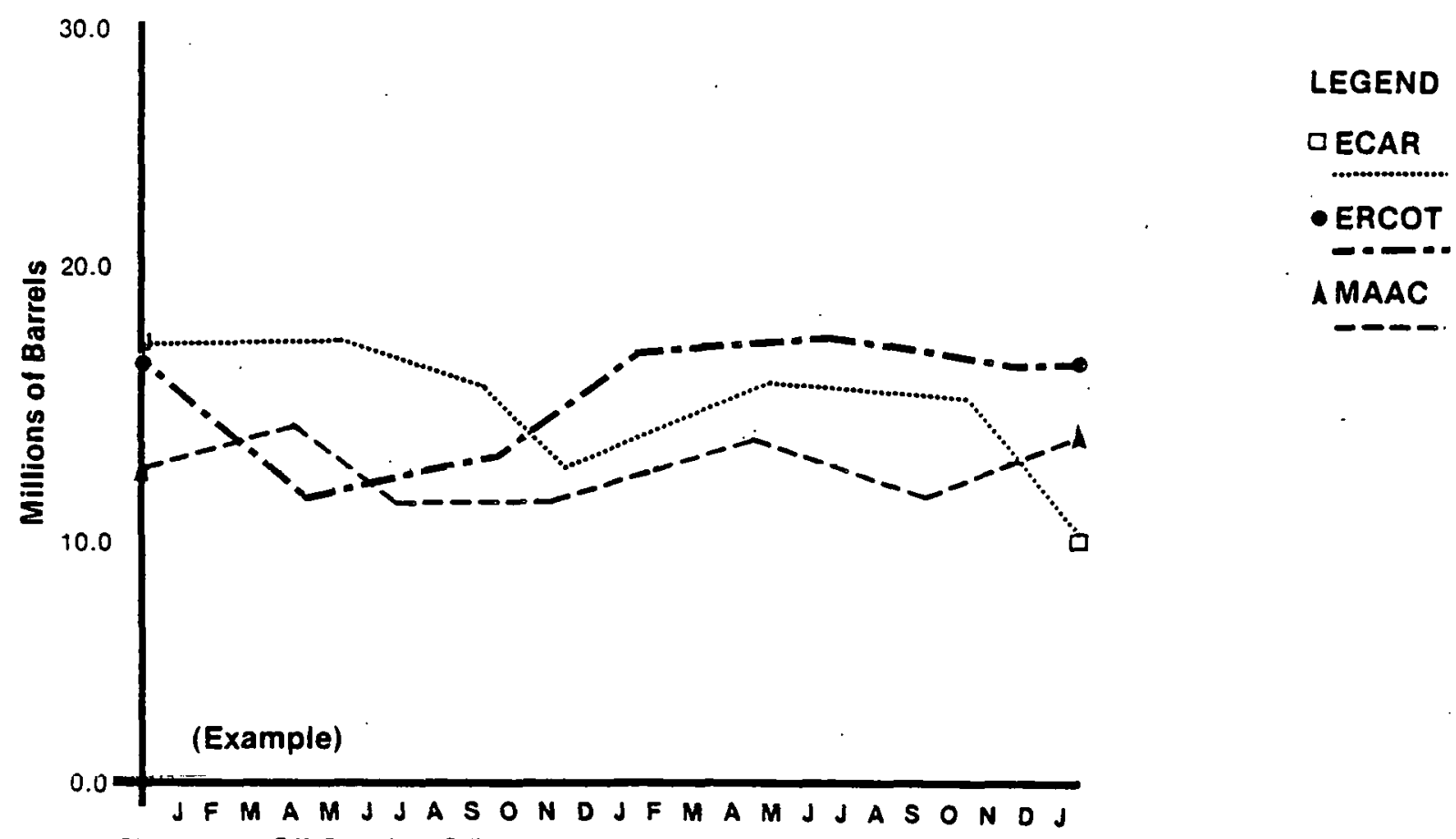

Figure 18. Oil Stocks, SERC Region, January 1978 - January 1980

Source - FPC Form 4

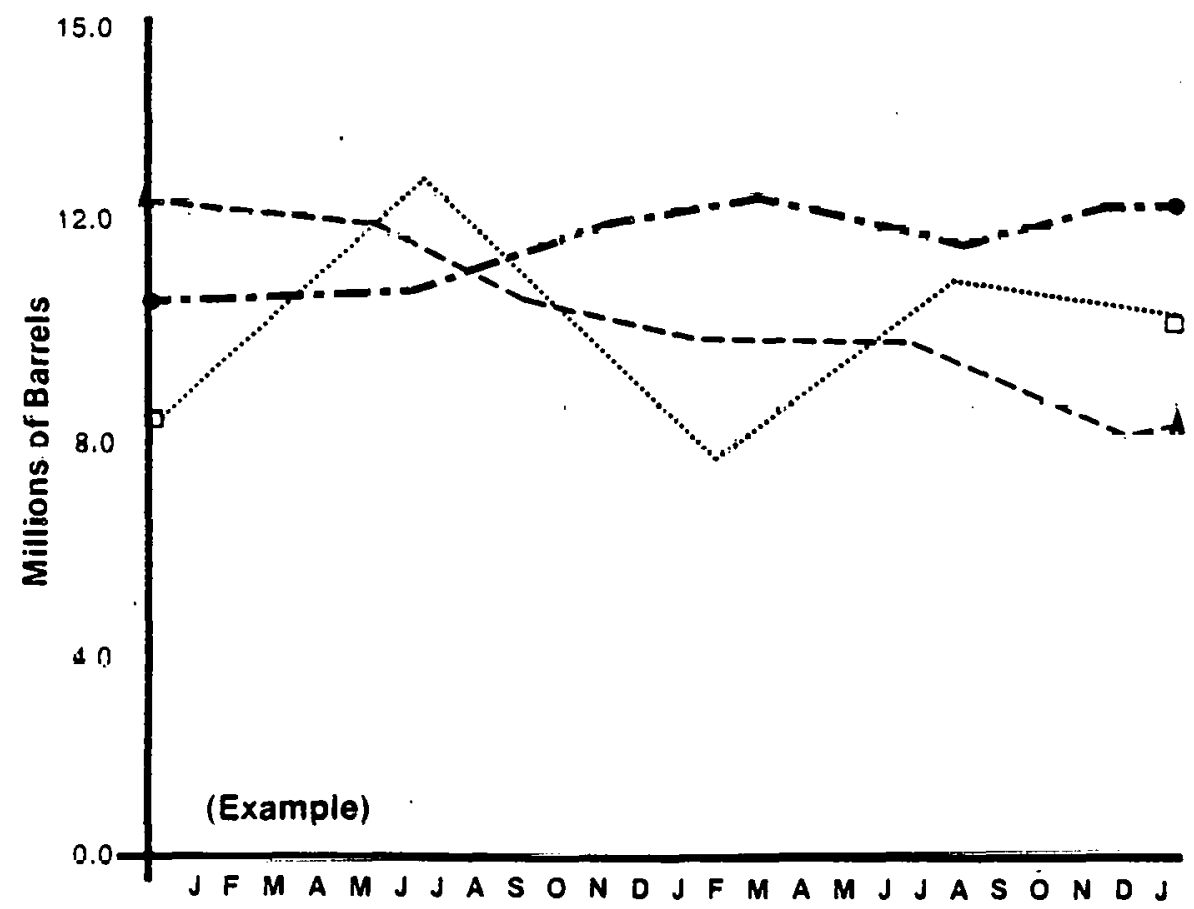

LEGEND

$\triangle M A I N$

- ---

- MARCA

- - - -

QNPCC

Figure 19. Oil Stocks, SWPP Region, January 1978 - January 1980

Source - FPC Form 4

Exhibit 13. NERC Regions Combined on 25 Month Graphs 
We see that data for Alaska and Hawaii are not graphed. Although their proportion of total's information is not great, we believe that the usefulness of the publication is damaged by not including all areas in graphic portrayal.

It is important that each section of graphs has graphic increments which are internally consistent. In other words, if a general increment of 2 , $4,6,8$, etc. is established, it must be universal within the section. Aberrations, such as $20,40,60,80$, etc., should not be placed within the section.

There is a general inconsistency in the number of months which are graphed. The discrepency is between the use of 13 and 25 months. The OEDO should consider which of the two is most appropriate and useful and employ it universally. We suggest using 25 months since more data is graphed and a better picture of the history of electrical generation is presented.

Consideration should also be given to the reasons for graphing only totals data. We do not understand why either state or census region totals are not graphed. Undoubtedly, should these two parts be graphed, the size of the EPM would increase greatly. However, if there are other reasons for merely graphing totals, they should probably be indicated in the highlights section.

As an addition to the graphics already employed, we offer Exhibit 14 as an example of the use of pie charts. We suggest that you consider increasing the use of bar charts (only one is now in use) and that pie charts be employed where appropriate.

\section{Graphical Presentation}

The requirements of a graph title and endnote are similar to those discussed for tables, but due to the lack of boxheads and line captions, even more importance must be placed on their clarity and completeness. 


\section{Net Electrical Generation}

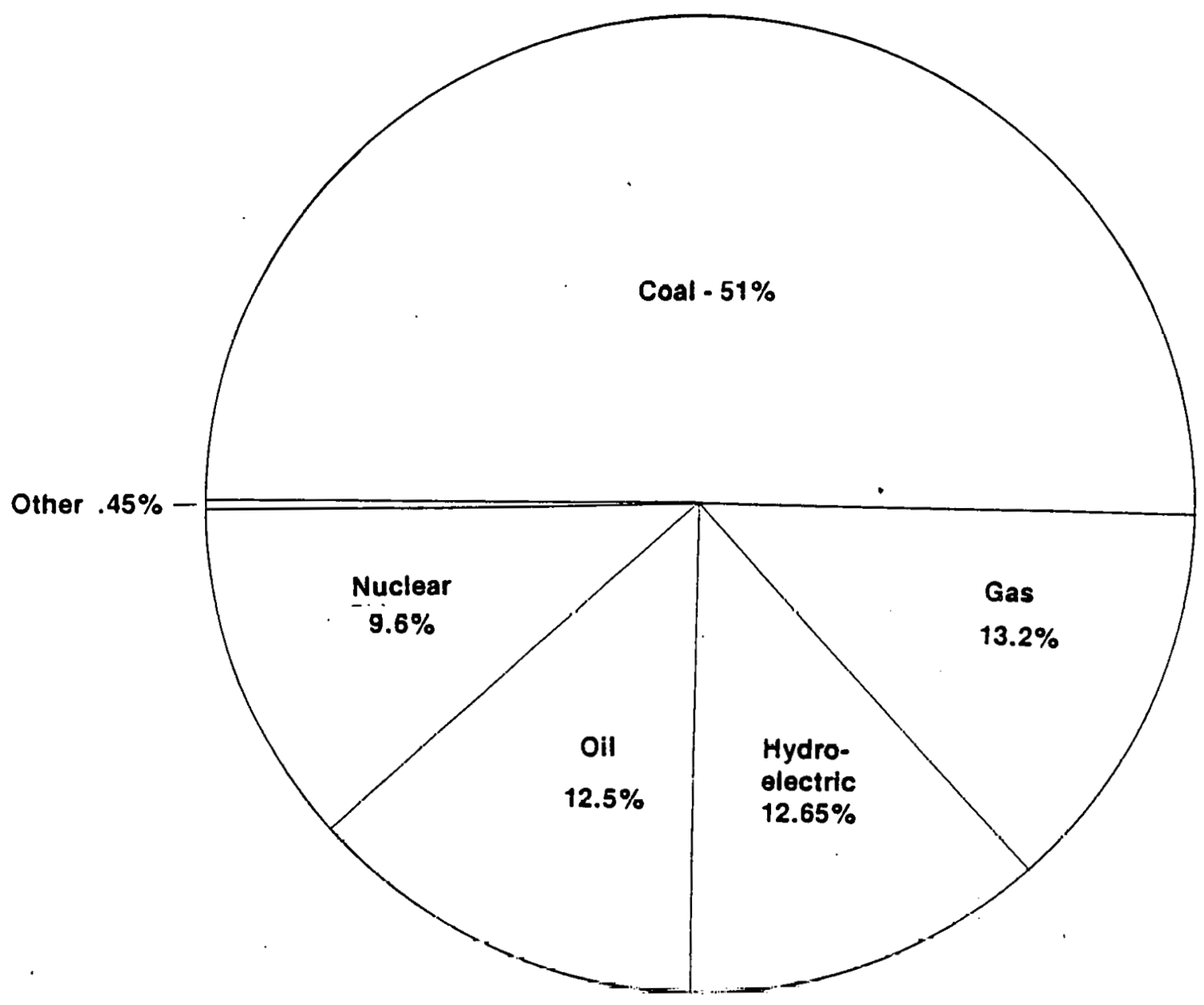

Figure 22. Net Electrical Generation by Fuel Source, U.S. Total, January 1980

Source - FPC Form 4 
Each graph title must identify:

- Energy Function (Stocks)

- Energy Source (Coal)

- Energy Function Adverbial Phrase (for the Generation of Electricity)

- Geographic Level of Aggregation

- Reported Time Interval (January 1978 - January ]980)

Each of these components is critical to identifying what the data points represent on a graph. The titling syntax recommended earlier for tables is applicable to graphs and we recommend that it be adopted throughout the EPM. Lacking line captions, all graphs especially require identification as to what geographic area is covered. This is already included in the NERC graphs (ECAR Region, etc.) and its addition to all graphs will eliminate any confusion and increase comparability.

As in the Review of Tables section of this report we recommend endnotes with expanded source information. Graphs endnotes will duplicate those of tables in almost all cases. Again, as space may prove to be a problem, we recommend placing one endnote section at the bottom of each page. Although EIA standards prohibits this, we feel the importance of this information is such that the standard should be reviewed. We have incorporated these recommendations on titles and endnotes in Exhibit 15.

As an aid to the reader we suggest placing numeric data on the graphs at appropriate points. This is not a major improvement but will facilitate the reading of the graphs. If it is not possible with OEDO's current graphics package it should be noted when considering future possible graphics capabilities.

\section{Cosmetic Review}

Earlier, we suggested that consideration be given to varying the number of graphs on a page. If the policy of two graphs to a page is retained, we then recommend that the graphs be reduced 25 percent to improve readability and attractiveness. Presently, the graphs are a bit too large for 
Receipts - Coal

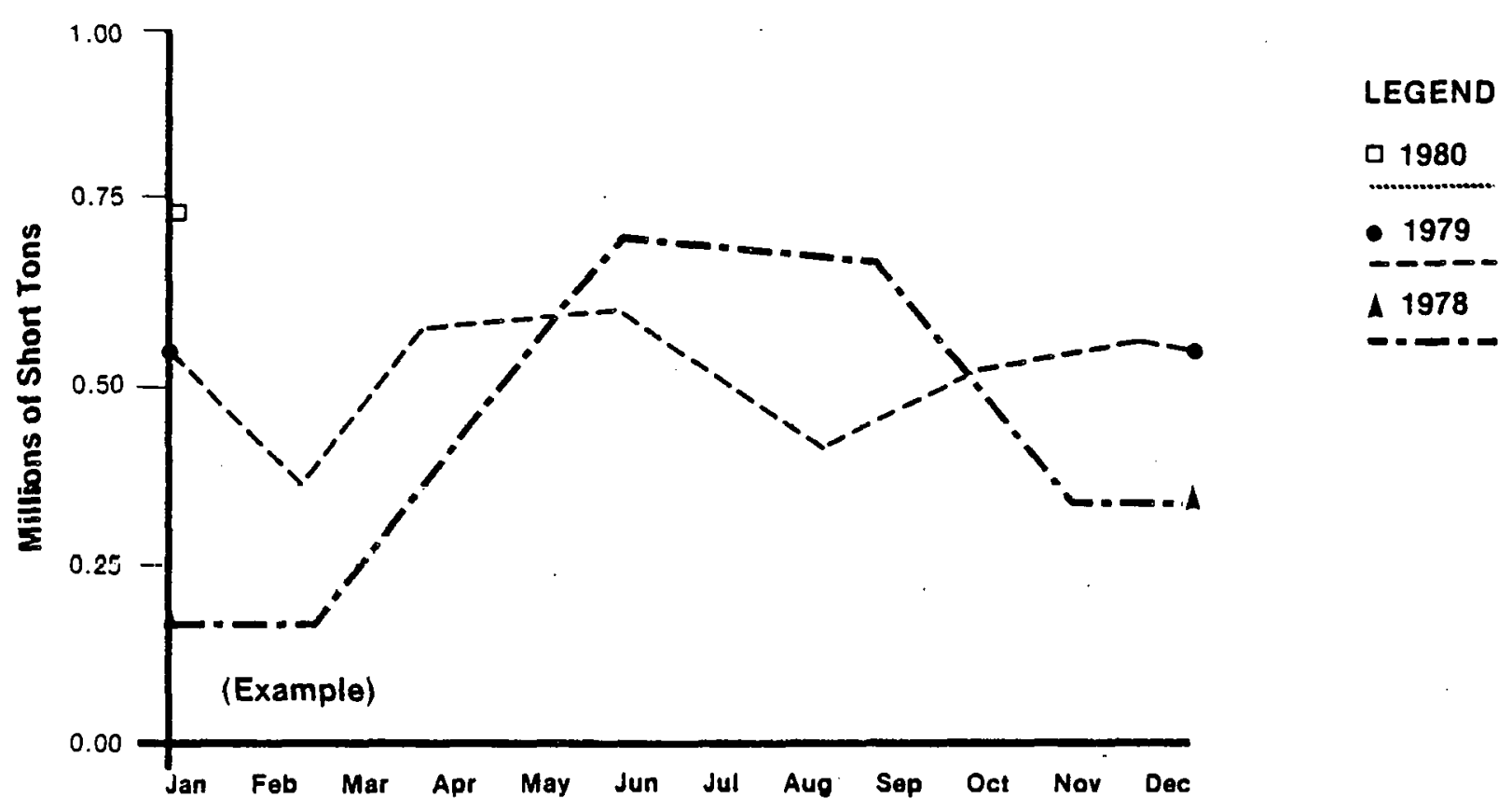

Figure 27. Receipts of Coal for the Generation of Electricity, NPPC Region (U.S.), January 1978 - January 1980.

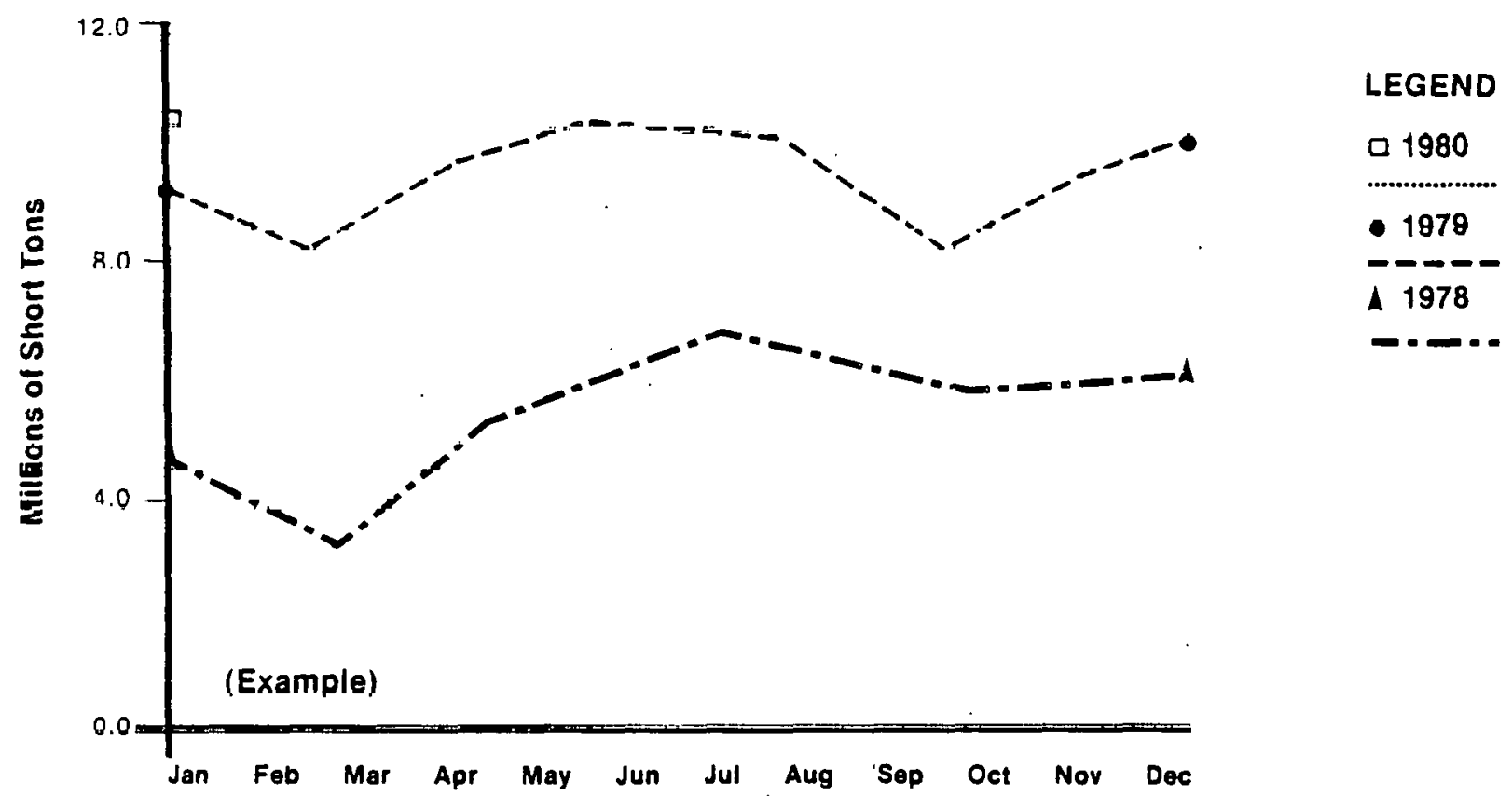

Figure 28. Receipts of Coal for the Generation of Electricity, SERC Region, Januạry 1978 - Janụạy 1980.

NOTE. Totais may r.ci equal sum of components due to independent rounding. Amount change and percent change are calculated before counding.

SCURCE. Feoeral Power Commission Form a23 reoresenting fossil fueied piants with a combined capacity of 25MW or greater. accountıng for acoroximately $95 \%$ of fossil fuei cadacily and $71 \%$ of : otal electric utility generation in the contiguous U.S. Definitions of terms and formulas are in Expianatory Notes at end of section.

Exhibit 15. NERC Graphs with Recommended Titles and Endnotes 
comfortable viewing, and need to be reduced to accomodate quick comprehension. Also, concerning graphs, similar publications have effectively employed shade graphs (Exhibit 16). If the computer generated graphics section of OEDO is capable of creating this kind of graph, it would be an extremely atractive portion of the publication.

The maps in the EPM should be reduced and have better resolution. Also, the type is generally too small, making it too difficult to understand what the map is trying to convey. Increasing the type size will significantly improve this problem.

On the $X$ and $Y$ axis, we suggest that type should be in initial capitals only. 


\section{Receipts - Coal}

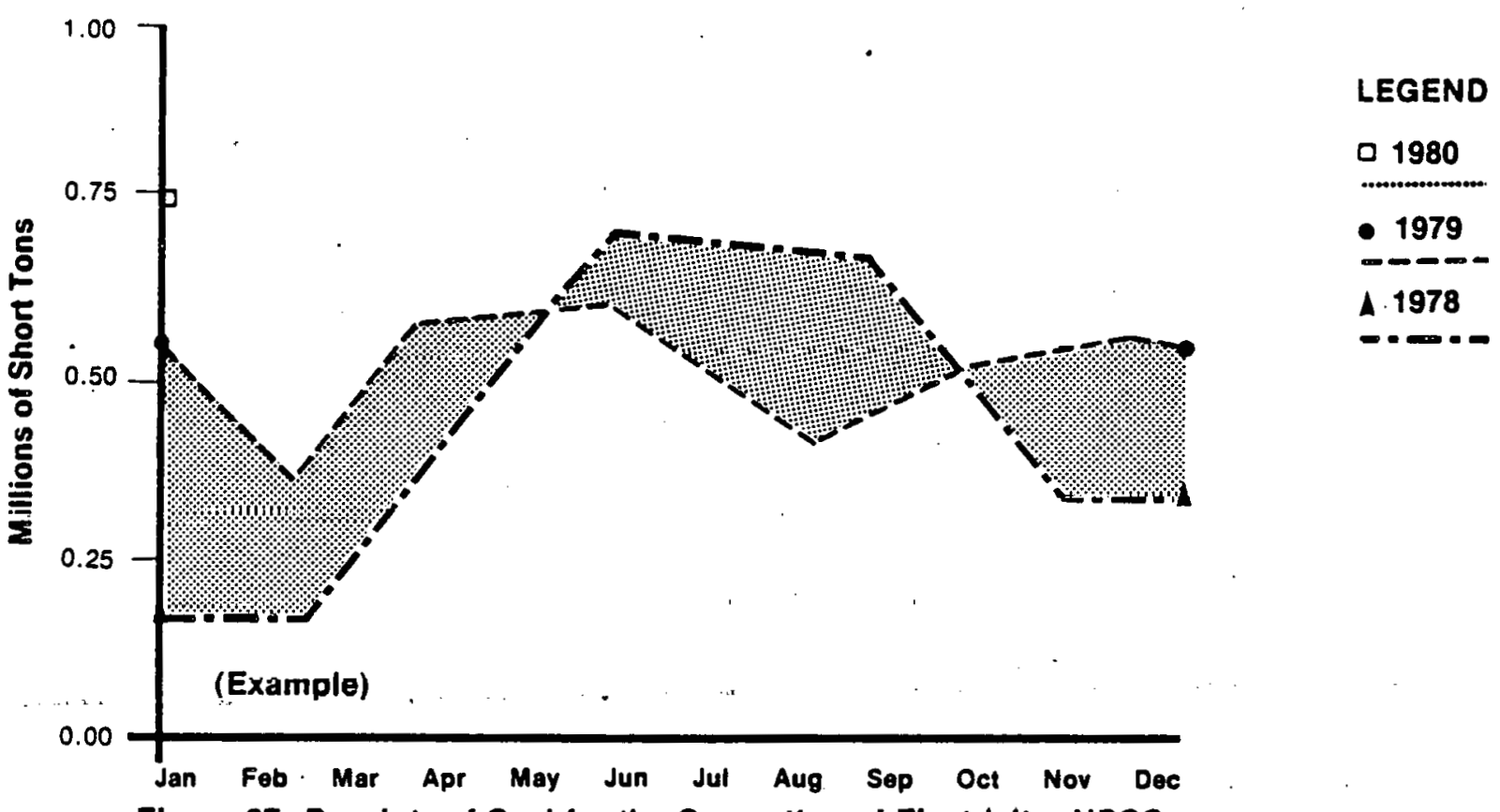

Figure 27. Receipts of Coal for the Generation of Electricity, NPCC Region, (U.S.), January 1978 - January 1980.

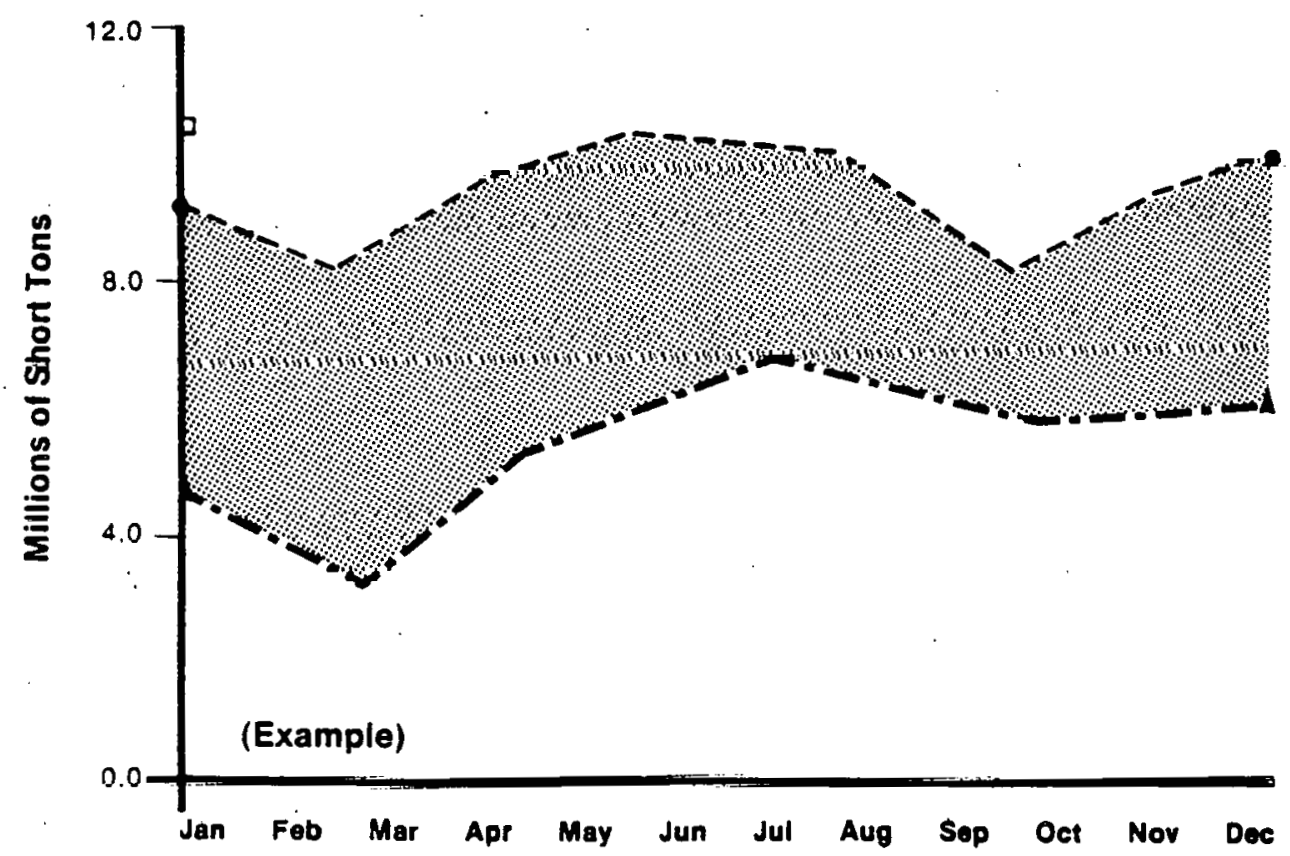

Figure 28. Receipts of Coal for the Generation of Electricity, SERC Region, January 1978 - January 1980.

NOTE: Totais may not equal sum of components due to independent rounding. Amount change and percent change are calculated before rounding.

SOURCE: Federal Power Commission Form 423 representing fossil fueled plants with a combined capacity of $25 \mathrm{MW}$ or greater. accounting tor approximately $95 \%$ of tossil fuel capacity and $71 \%$ of total electric utility generation in the contiguous U.S Definitions of :erms and formulas are in Explanatory Notes at end of section.

\section{Exhlblt 16. NERC Graphs with Shading}

